New data from Jebel Moya and Shaqadud (central Sudan): Implications for Late Mesolithic interconnectivity with the Sahara

Dr Michael Brass

University College London

United Kingdom

E-mail: michael.brass@ucl.ac.uk

Professor Ahmed H. Adam

Department of Archaeology

University of Khartoum

E-mail: ahmedaba77@yahoo.com

Mr Joss Wellings

Independent researcher

London

E-mail: josswellings@hotmail.co.uk

Corresponding author: Dr Michael Brass 


\section{New data from Jebel Moya and Shaqadud (central Sudan): Implications for Late Mesolithic interconnectivity with the Sahara}

\section{Abstract}

Building upon Brass' previous research on Jebel Moya, which included a comprehensive re-analysis of the pottery from Wellcome's 1911-14 expeditions curated at the British Museum, new research activities by the University College London - University of Khartoum Expedition to the Southern Gezira project have included locating and examining for the first time the late Mesolithic sherds from Jebel Moya curated at the national museum in Khartoum. Representative samples from the sites of Shaqadud Midden and Shaqadud S21 at the British Museum have also been re-examined. The aims of these activities were three-fold: to test the reliability and cohesiveness of and patterning in the Shaqadud collection through the expanded application of attribute analysis, to determine if Caneva's observations of décor patterns on Jebel Moya late Mesolithic sherds could be replicated and to obtain better visibility into the nature of its pottery assemblage from this time, and to use the resulting data to test the viability of the central Sudan being a fulcrum of cultural interchanges during the late $6^{\text {th }}$ and early $5^{\text {th }}$ millennium BC. We conclude that there was a piecemeal establishment of networks along which there was diffusion of ideas and animals, and perhaps low numbers of people, into the central and south-central Sudan.

The Early to Middle Holocene periods of the Central Sudan and the central Sahara have often been the subject of hypotheses of a trans-Saharan cultural horizon (Mohammed-Ali and Khabir 2003) or trade links between regions ca. $4000 \mathrm{~km}$ apart (Figures 1a, b). The latter hypothesis was originally proposed by Isabella Caneva (1993; Caneva and Marks 1990, Caneva and Osman 1990) and taken up by select scholars such as Elena Garcea (1993b). It is predicated in particular upon previously reconstructed timings and distribution patterns of wavy line, dotted wavy line (DWL) and APS décor in general.

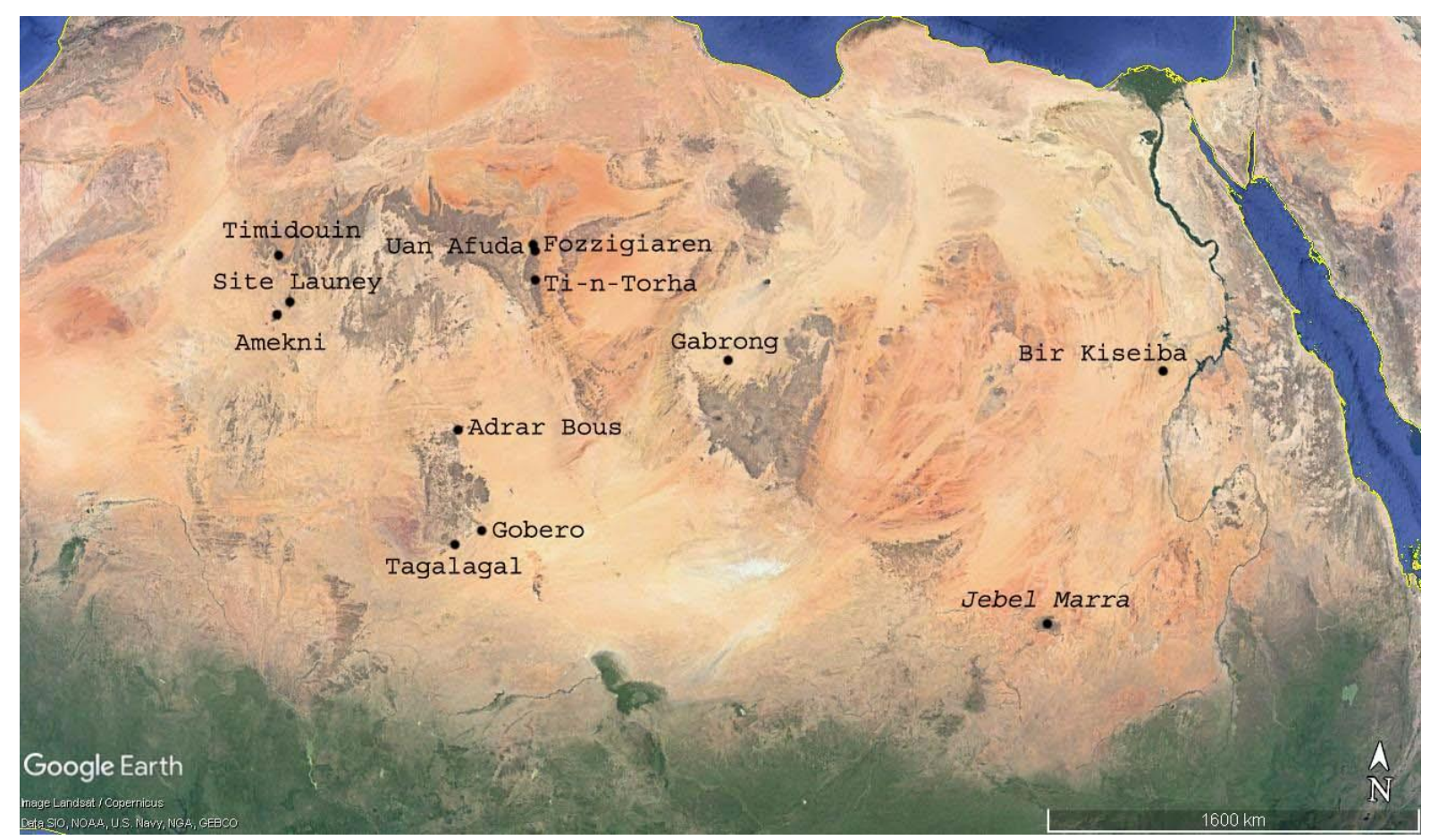




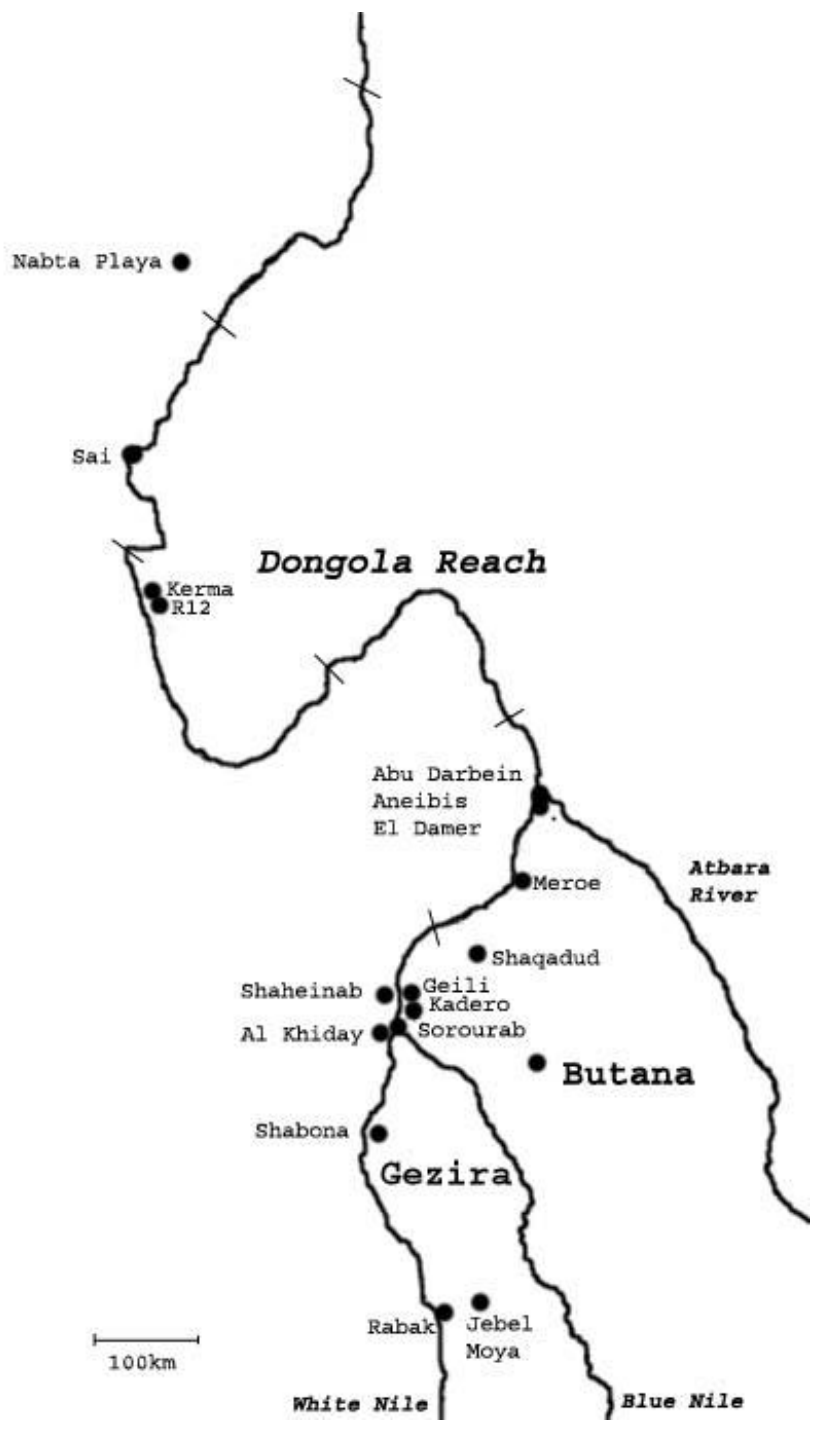

Figures 1a, b. (a) Early Holocene sites in the central Sahara with classically-defined Dotted Wavy Line pottery. (b) Important sites from the south-central and central Sudan and Nubia.

Caneva's hypothesis consists of two components: (1) A claimed earlier appearance of DWL in the central Sahara than in the Central Sudan (late $6^{\text {th }}$ millennium $B C^{1}$ ), and $(2)$ short dotted wavy line and smocking décor appearing in the late Mesolithic and Neolithic respectively of the central Sudan. At the time that Caneva first proposed her hypothesis, there were rare instances of sherds falling within the broad and inadequate typological category of dotted wavy line were known in central Sudanese contexts pre-dating $5000 \mathrm{BC}$. Even so, she focused on a specific type of dotted wavy line, the short DWL, in her brief examination of the late Mesolithic Jebel Moya sherds curated at the British Museum, the shape, size and technique of which have comparisons with Shaqadud as well as the Kabbashi levels dated to ca. 5100 BC) (Caneva 1987b, 1991; Caneva and Marks 1990). She noted earlier occurrences in the Sahara (see, for example, Bailloud 1969: Figure 3A and p. 37). While not positing that there were shared generic cultural traits (e.g. Camps-Fabrer 1966; Camps 1974; Sutton 1974, 1977), she proposed cultural contact between the central Sahara and parts of the Upper Nile Valley or White Nile, between ca. 6200 - 5800 BC (Caneva 1991: 267).

\footnotetext{
${ }^{1}$ All dates were re-calibrated at $95.4 \%$ confidence interval using the IntCal 13 calibration curve on OxCal 13.
} 
While the DWL, as traditionally defined, is broadly contemporary in both the Sahara and the central Sudan (Salvatori 2012), the core of Caneva's hypothesis ultimately hinges upon her analyses of pottery from two sites in particular: Jebel Moya and Shaqadud Midden. However, the stratigraphic and temporal reliability of the Shaqadud Midden sequence has recently been questioned by Sandro Salvatori (2012). Salvatori (2012) has further argued against using selective décor traits in isolation as proxies for the establishment of networks along which people and/or goods and ideas transverse.

In order to attempt to address these issues, we examine for the first time the extant Mesolithic pottery from Jebel Moya curated at the national museum in Khartoum and integrate it with a re-examination of samples from Shaqadud S21 and Midden curated at the British Museum. The results of our attribute analysis approach expand upon Brass' 13 Mesolithic sherds from Jebel Moya at the British Museum and helps refine the reliability of previous studies on the Shaqadud collection. We further integrate the results with an examination of the literature on pottery from the central Sahara, from elsewhere in the Gezira and central and northern Sudan in order to shed further light on what network connections may have been present in the late Mesolithic of central and south-central Sudan, both locally and between it and the wider Sahara. We conclude that craft communities were porous and that there was a piecemeal establishment of networks which allowed diffusion of ideas and domesticated animals into the central and south-central Sudan in the few centuries overlap between the end of the late Mesolithic and the early Neolithic, at the end of the $6^{\text {th }}$ millennium and start of the $5^{\text {th }}$ millennium $B C$.

\section{Jebel Moya - Late Mesolithic}

Jebel Moya was first excavated by the founder of the Wellcome Trust, Henry Wellcome, over four seasons from January 1911 to April 1914 (Addison 1949). The occupied valley is formally known as Site 100 but will be referred to here as Jebel Moya. It is approximately $250 \mathrm{~km}$ south south-east of Khartoum and ca. $30 \mathrm{~km}$ west of Sennar, and the valley is ca. 10.4 hectares in size. A fifth of the valley floor was excavated. It is the largest pastoral cemetery in Africa. Wellcome's excavation yielded a recorded 3135 human burials from 2791 graves, assigned to the third and last of the three occupational phases. The first phase is dated to the late $6^{\text {th }}$ millennium $B C$ and was said to be represented by only small disturbed deposits left behind in the lowest stratum (Addison 1949), but field observations during the 2017 season by the University College London - University of Khartoum Expedition to the Southern Gezira (Sudan) (co-directed by Brass and Adam) show that the lowest Stratum remains prevalent with embedded late Mesolithic sherds.

Brass (2016: 28-70) did a thorough re-examination was undertaken of the Jebel Moya pottery repertoire currently stored at the British Museum. It was essential to both re-evaluate and supplement the published descriptive information and illustrations (Addison 1949, Caneva 1991, Gerharz 1994, Manzo 1995). Brass (2016, Brass and Schwenniger 2013) also argued against the appropriateness of both Type Variety and typological classificatory systems, including Caneva's commonly used system for the Sudan and the Sahara. The variety and types of tools which are used to produce the motifs may reflect stylistic and technological diversity and/or social choice. The recognition of aspects of décor as socially embedded technological choices (Gosselain 2000, Gosselain and Livingstone Smith 2013, Gosselain 1992) has permitted a move away from typological categories towards an understanding of the nature and use of the tools used to produce the range of pottery (Haour et al. 2010, Keech McIntosh 1995, MacDonald 2011, Mayor et al. 2005, Vella Gregory 2017). The identification of tools and the motor actions are thereby the starting point and not an outcome or side effort in the analysis; their use helps minimise bias in determining the highest-level grouping of attributes. This approach facilitated their grouping into temporally significant attribute clusters and laid the foundation for an integrated approach to ceramic studies for material from future excavations in the southern Gezira. 
In essence, typological classificatory systems ultimately lack sufficient fluidity and subtlety to (a) fully explore situations where overlapping pottery tradition transmissions have occurred, (b) avoid imposing a mask of relative homogeneity upon diverse pottery traditions, and (c) establish chains of transmission in attributes between pottery traditions from neighbouring regions. There is also a danger that typologies, in seeking to have a broad inter-regional utility, may become so stretched or fuzzy as to be unreliable (e.g. any 'wavy line' motif no matter how made or placed becomes a signal of a 'wavy line' type). Continuing on from Brass' (2016) application, we do not seek to create a taxonomic hierarchy which would fossilise the diagnostic nested, reoccurring co-variables. Instead, we continue employing an attribute system which permits the selection of the appropriate attributes pertinent to the questions being asked.

To date, three distinct pottery assemblages have been discerned: Assemblage 1 is late Mesolithic (late $6^{\text {th }}$ millennium BC), Assemblage 2 is bracketed between ca. $1800-800 \mathrm{BC}$ and Assemblage 3 between ca. A.D. $100-600$ BC (Brass 2016: Table 3.11). The Assemblage 1 sherds were mostly from the lowest stratum (Stratum D) or on its surface. This portion of the study focuses on the late Mesolithic sherds curated at the national archaeology museum in Khartoum from Wellcome's excavations. The museum's Jebel Moya sherds have never before been studied. A total of 30 sherds were located, 23 of which were from the surface of Stratum $D$ and 7 from Stratum $D$ itself. The information was entered into a spreadsheet with each individual sherd recorded using standardised parameters:

- Sherd number and stratum of origin

- The part or parts of the vessel under description

- The maximum thickness of the sherd

- The minimum thinness of the sherd

- The rim angle

- The type of rim

- The internal diameter of the vessel

- The composition of the sherd's temper

- The presence or absence of burnishing

- The presence or absence of a slip

- Tools used in generating motifs

- The form of motifs generated by tools

- The location of the motifs (décor)

The reasoning behind these categories is to keep the information collected as clear and concise as possible on the dimensions, condition and specific features of the pottery. The rim angle or orientation was measured to determine how restricted or open the vessel was. Plastic callipers were used to measure the thickness and thinness of the Shaqadud sherds at the British Museum and digital callipers for the Jebel Moya collection at the national museum in Khartoum. The vast majority of the sherds are of a similar hue having been fired in an oxygenated environment. A photographic record of the sherds was also compiled.

\section{Assemblage 1 at the National Museum (Khartoum)}

Brass and Wellings examined all the Jebel Moya trays looking for Late Mesolithic sherds. The Late Mesolithic sherds were restricted to specific trays, which contained only two intrusive Assemblage 2 rim sherds (see below). The trays were labelled with their provenance. It must be noted that no Late Mesolithic sherds were identified amongst the Assemblage 2 and 3 sherds in the remaining Jebel Moya trays. The derivation of the sherds from the surface of Stratum $D$ and from within the lowest 
Stratum, Stratum D, fits within Brass' (2016) reconstructed frequency distribution of assemblages through the stratigraphic sequences. The label with the former states "D surface Kh. 8242" and the latter "D stratum Kh. 8241", but Frank Addison's (1949) site report does not state where Kh. 8241 and 8442 are situated in the site; the excavation squares are labelled differently and section numbers are labelled as section, so the provenance and context cannot be more specifically identified. Stratum D is present through the site. Furthermore, our expedition's renewed fieldwork at Jebel Moya, which will be the subject of forthcoming papers, has confirmed the validity of the internal coherence, temporal significance and stratigraphic distribution of the three assemblages.

Of the 30 sherds, a total of 7 are rim \& bodies (Table 1). Five are simple (straight) thin rims, 1 is a simple thick rim and the remaining rim is slightly everted. The latter rim also has stylus incised chevrons with a maximum and minimum thickness of $1.6 \mathrm{~cm}$ and $0.6 \mathrm{~cm}$ respectively, and a gritted sand paste temper, which together mark it as an intrusive early Assemblage 2 sherd. This latter sherd unusually has no burnishing, which is otherwise present in $83.65 \%$ of the British Museum's Assemblage 2 sherds (Brass 2016: 59). Another Assemblage 2 sherd is the rim with SL-ABD (stamped lines of angular and banded dots) décor, also without burnishing. The remaining five sherds also have no burnishing, while all seven sherds are slipped, in line with Brass' observation of the 13 extant Assemblage 1 sherds from the British Museum and Caneva's (1991) earlier examination of the then extant Assemblage 1 sherds also at the British Museum.

\begin{tabular}{|l|c|c|}
\hline \multicolumn{1}{|c|}{ Rim form } & Surface, Stratum D & Stratum D \\
\hline Everted & 0 & $1(14.29 \%)$ \\
\hline Simple, thin & $4(57.14 \%)$ & $1(14.29 \%)$ \\
\hline Simple, thick & 0 & $1(14.29 \%)$ \\
\hline
\end{tabular}

Table 1. Jebel Moya. The different rim forms and their respective percentages.

The 13 extant Late Mesolithic sherds at the British Museum do not include the Dotted Wavy Line (DWL) sherds reported by Caneva (1991). However, DWL is among the décor on the Late Mesolithic sherds from the Khartoum museum, which confirms not only Caneva's observations and the photos reproduced in Addison's (1949) site report but also our subsequent fieldwork observations. Analysis of the single attribute occurrences of the seven rims with décor (Tables 2 and $3 a, b$ ) show a different décor per rim.

\begin{tabular}{|l|l|c|c|}
\hline \multicolumn{1}{|c|}{ Tool } & \multicolumn{1}{|c|}{ Motor action } & Surface, Stratum D & Stratum D \\
\hline $\begin{array}{l}\text { Comb (evenly } \\
\text { serrated) }\end{array}$ & & & \\
\hline & SL-ABD & & $1(14.29 \%)$ \\
\hline & SL-D & $1(14.29 \%)$ & \\
\hline & SL-PZD & $1(14.29 \%)$ & $1(14.29 \%)$ \\
\hline $\begin{array}{l}\text { Comb (unevenly } \\
\text { serrated) }\end{array}$ & SL-SD & & \\
\hline & & & \\
\hline & SL-UADS & $1(14.29 \%)$ & \\
\hline Stylus & US & $1(14.29 \%)$ & $1(14.29 \%)$ \\
\hline & & & \\
\hline
\end{tabular}

Table 2. Jebel Moya. Rim sherds: Single attribute occurrences of décor tools and the corresponding motor actions. \% occurrence is calculated against the number of overall rims.

\begin{tabular}{|l|l|l|l|}
\hline & Simple, thin & Simple, thick & Everted \\
\hline
\end{tabular}




\begin{tabular}{|l|c|l|l|}
\hline IC & 0 & 0 & 0 \\
\hline SL-ABD & 0 & 0 & 0 \\
\hline SL-D & $1(14.29 \%)$ & 0 & 0 \\
\hline SL-PZD & $1(14.29 \%)$ & 0 & 0 \\
\hline SL-SD & 0 & 0 & 0 \\
\hline SL-UADS & $1(14.29 \%)$ & 0 & 0 \\
\hline US & $1(14.29 \%)$ & 0 & 0 \\
\hline
\end{tabular}

Table 3a. Jebel Moya. Co-occurrences of rim types and corresponding motor actions, surface of Stratum D. \% occurrence is calculated against the number of overall rims.

\begin{tabular}{|l|c|c|c|}
\hline & Simple, thin & Simple, thick & Everted \\
\hline IC & 0 & 0 & $1(14.29 \%)$ \\
\hline SL-ABD & 0 & $1(14.29 \%)$ & 0 \\
\hline SL-D & 0 & 0 & 0 \\
\hline SL-PZD & 0 & 0 & 0 \\
\hline SL-SD & $1(14.29 \%)$ & & 0 \\
\hline SL-UADS & 0 & 0 & 0 \\
\hline US & 0 & 0 & 0 \\
\hline
\end{tabular}

Table 3b. Jebel Moya. Co-occurrences of rim types and corresponding motor actions, Stratum D. \% occurrence is calculated against the number of overall rims.

Motor action codes for Jebel Moya and Shaqadud

\begin{tabular}{|c|c|c|c|}
\hline$A P S-D$ & APS, paired dashes & $A P S-P D S B$ & $\begin{array}{l}\text { APS, paired dashed straight } \\
\text { banded }\end{array}$ \\
\hline$A P S-P L$ & APS, dotted paired lines & $A P S-S M$ & APS, smocking \\
\hline$D B A L$ & $\begin{array}{l}\text { Dragged banded arching } \\
\text { lines }\end{array}$ & $D B L$ & Dragged banded lines \\
\hline $\mathrm{DH}$ & Dragged herringbone & $D P C$ & Dragged packed chevrons \\
\hline$D R W L$ & Dragged wavy lines & $D R W L-S$ & Dragged wavy lines - short \\
\hline$D S W L$ & Dragged stylus wavy lines & DTWL & Dotted wavy line \\
\hline DTWL-S & Dotted wavy line, short & $G L$ & Grooved lines \\
\hline IC & Incised chevrons & IF & Impressed fingernails \\
\hline IL & Incised lines & $I P C$ & Incised packed chevrons \\
\hline IV & Incised Vs & $I W L$ & Incised wavy lines \\
\hline$P E S-H L$ & $\begin{array}{l}\text { Plain edge shell, continuous } \\
\text { herringbone lines }\end{array}$ & $S L-A B D$ & $\begin{array}{l}\text { Stamped lines, angular and } \\
\text { banded dots }\end{array}$ \\
\hline$S L-A D$ & Stamped lines, angular dots & $S L-A D S$ & $\begin{array}{l}\text { Stamped lines, angular } \\
\text { dashes }\end{array}$ \\
\hline$S L-B L D$ & $\begin{array}{l}\text { Stamped lines, banded } \\
\text { lines of dashes }\end{array}$ & $S L-B P D$ & $\begin{array}{l}\text { Stamped lines, banded } \\
\text { packed dots }\end{array}$ \\
\hline$S L-C P D$ & $\begin{array}{l}\text { Stamped lines, continuous } \\
\text { packed dashes }\end{array}$ & $S L-D$ & Stamped lines, dotted \\
\hline$S L-D D$ & $\begin{array}{l}\text { Stamped line, dotted } \\
\text { droplets }\end{array}$ & $S L-D W L$ & $\begin{array}{l}\text { Stamped lines, dashed } \\
\text { wavy lines }\end{array}$ \\
\hline$S L-D W L S$ & $\begin{array}{l}\text { Stamped lines, small } \\
\text { dashed wavy lines }\end{array}$ & $S-G L$ & Stylus, grooved lines \\
\hline$S-I Z$ & Stylus, incised zigzags & $S L-O D$ & $\begin{array}{l}\text { Stamped lines, overlapping } \\
\text { dots }\end{array}$ \\
\hline$S L-P D$ & $\begin{array}{l}\text { Stamped lines, plain } \\
\text { dashed }\end{array}$ & $S L-P Z D$ & $\begin{array}{l}\text { Stamped lines, packed } \\
\text { zigzag dots }\end{array}$ \\
\hline$S L-S$ & Stamped lines, square & $S L-S D$ & $\begin{array}{l}\text { Stamped lines, spaced } \\
\text { dashes }\end{array}$ \\
\hline$S L-S Z D$ & $\begin{array}{l}\text { Stamped lines, spaced } \\
\text { zigzag dots }\end{array}$ & $S L-T T$ & $\begin{array}{l}\text { Stamped lines, triangular } \\
\text { toothed }\end{array}$ \\
\hline SL-UADS & $\begin{array}{l}\text { Stamped lines, unevenly } \\
\text { serrated angular dashes }\end{array}$ & $S L-U C P D$ & $\begin{array}{l}\text { Stamped lines, unevenly } \\
\text { serrated continuous packed } \\
\text { dashes }\end{array}$ \\
\hline
\end{tabular}




\begin{tabular}{|l|l|l|l|}
\hline SL-UD & $\begin{array}{l}\text { Stamped lines, unevenly } \\
\text { serrated dots }\end{array}$ & SL-UPZD & $\begin{array}{l}\text { Stamped lines, unevenly } \\
\text { serrated packed zigzag dots }\end{array}$ \\
\hline SL-US & $\begin{array}{l}\text { Stamped lines, unevenly } \\
\text { serrated }\end{array}$ & SL- USD & $\begin{array}{l}\text { Stamped lines, unevenly } \\
\text { serrated spaced dashes }\end{array}$ \\
\hline SL-USDS & $\begin{array}{l}\text { Stamped lines, unevenly } \\
\text { serrated dots }\end{array}$ & $S-V$ & $\begin{array}{l}\text { V-shape impressions, } \\
\text { herringbone }\end{array}$ \\
\hline S-WL & Stylus-dragged wavy lines & & \\
\hline
\end{tabular}

Six of the 7 rim décor was produced by a comb, with the remaining rim's décor produced by a stylus (incised chevrons). Both evenly serrated (6) and unevenly serrated (1) combs were used. For the two Assemblage 2 rim-body sherds, an evenly serrated comb-stamped lines of angular and banded dots and stylus-incised chevrons are present. On the Late Mesolithic rim sherds, evenly serrated combs were used for stamped, packed zigzag dotted lines; stamped dotted lines; and lines of stamped, spaced dashes; while unevenly serrated combs were used for stamped lines and angular dashed lines.

The 30 body and rim-body sherds display a wide variety of décor motor actions, although their tools remain restricted to combs (even and unevenly serrated) and styluses (Figures 2, 3) (Table 4). Of the two rim-body Assemblage 2 sherds and the one A2 sherd body, the body décor consists of banded comb grooved lines, comb stamped lines of angular and banded dots, grooved lines and a comb stamped dotted line; all are evenly serrated combs. For the Late Mesolithic sherds, the most common are comb stamped packed zigzag dotted lines (30\%). The next most common are comb stamped continuous packed dashed lines (16.67\%). The remainder of the motor actions are fairly evenly numbered, either with singular and double occurrences. Evenly serrated comb motor actions comprise dragged banded lines, dragged packed chevrons, dragged wavy lines (long and short, with short defined as between 2-4mm), dotted wavy line (long and short), heavily worn stamped lines, lines of continuous packed stamped dashes, lines of stamped angular dots, dotted stamped lines of dashed wavy lines (long and short), plain dashed stamped lines, square toothed stamped lines, lines of stamped spaced zigzag dots, and triangular toothed stamped lines. The rare instances of unevenly serrated comb comprise worn stamped lines and lines of stamped dots. There are equally rare instances of stylus incised lines and incised packed chevrons. Importantly, there were no wavy line décor on the extant British Museum Mesolithic sherds when they were first re-examined by Caneva (1991) and later by Brass (2016); although there are photos in Addison (1949: Plates XCIV), this is the first independent confirmation of their occurrence and the first time that they have been adequately described.

\begin{tabular}{|c|c|c|c|}
\hline Tool & Motor action & Surface, Stratum D & Stratum D \\
\hline \multicolumn{4}{|l|}{$\begin{array}{l}\text { Comb (evenly } \\
\text { serrated) }\end{array}$} \\
\hline & DBAL & 0 & $1(3.33 \%)$ \\
\hline & DBL & $1(3.33 \%)$ & $1(3.33 \%)$ \\
\hline & DPC & $1(3.33 \%)$ & \\
\hline & DRWL & $2(6.67 \%)$ & \\
\hline & DRWL-S & 2 (6.67\%) & \\
\hline & DTWL & 0 & $1(3.33 \%)$ \\
\hline & DTWL-S & $1(3.33 \%)$ & \\
\hline & GL & 0 & $1(3.33 \%)$ \\
\hline & SL & $1(3.33 \%)$ & \\
\hline & SL-ABD & 0 & $1(3.33 \%)$ \\
\hline & SL-BLD & 0 & $1(3.33 \%)$ \\
\hline & SL-CPD & $5(16.67 \%)$ & $1(3.33 \%)$ \\
\hline
\end{tabular}




\begin{tabular}{|l|l|c|c|}
\hline & SL-AD & $1(3.33 \%)$ & \\
\hline & SL-D & $1(3.33 \%)$ & $1(3.33 \%)$ \\
\hline & SL-DWL & 0 & $2(6.66 \%)$ \\
\hline & SL-DWLS & 0 & $1(3.33 \%)$ \\
\hline & SL-PD & $1(3.33 \%)$ & \\
\hline & SL-PZD & $9(30 \%)$ & \\
\hline & SL-S & $1(3.33 \%)$ & \\
\hline & SL-SZD & $1(3.33 \%)$ & \\
\hline & SL-TT & $1(3.33 \%)$ & \\
\hline $\begin{array}{l}\text { Comb (unevenly } \\
\text { serrated) }\end{array}$ & & & \\
\hline & & & \\
\hline & SL-US & $2(6.67 \%)$ & \\
\hline Stylus & SL-USD & 0 & $1(3.33 \%)$ \\
\hline & & $1(3.33 \%)$ & \\
\hline & IL & $1(3.33 \%)$ & \\
\hline
\end{tabular}

Table 4. Jebel Moya. Body sherds: Single attribute occurrences of décor tools and the corresponding motor actions, and the percentage within the collection.

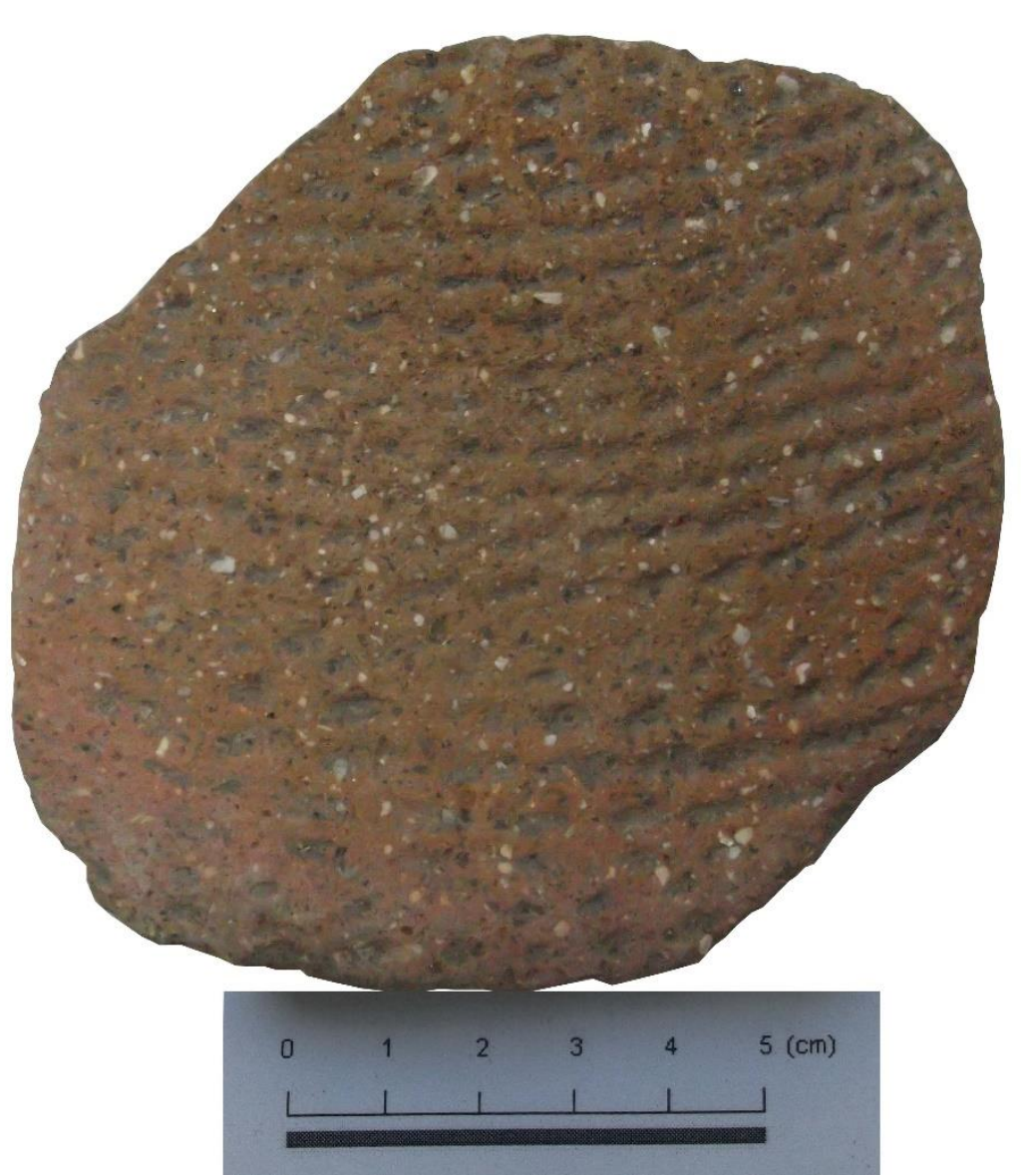

Figure 2. Jebel Moya, Late Mesolithic: Comb-stamped lines, packed rocker zigzag dots. 

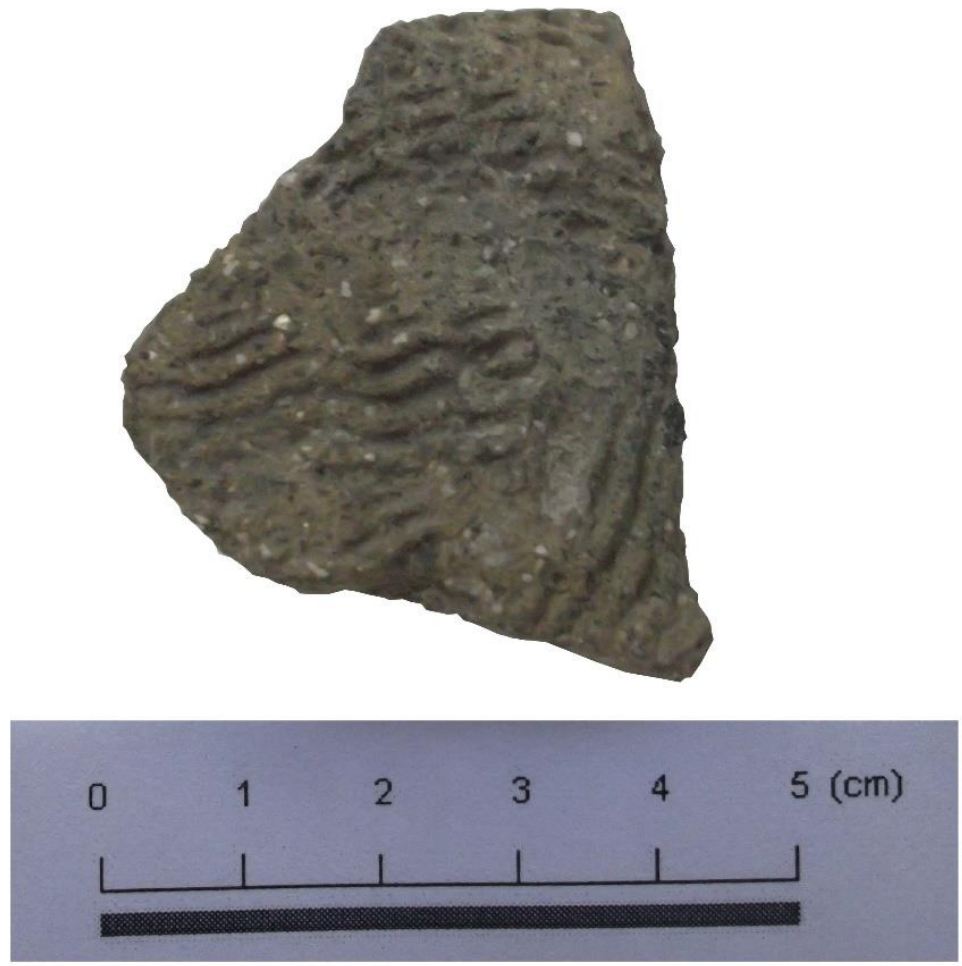

Figure 3. Jebel Moya, Late Mesolithic. Comb-dragged short wave.

The motor actions in common between the sherds on the surface of Stratum D and those within is the lines of continuous packed stamped dashes. Exclusive motor action instances on body sherds from the surface of Stratum D are dotted wavy line (long only, with short only present within Stratum D), dashed wavy lines (long and short), and the lines of unevenly serrated stamped dots. It is unknown if any significance can be attached to these differences given the small sample size. Only future seasons of fieldwork at Jebel Moya, with excavation down to the bedrock directly below Stratum D will potential resolve questions regarding the exact nature of the Mesolithic occupation and composition of the related pottery assemblage(s).

While visual examination of the paste of the British Museum Late Mesolithic sherds revealed that it predominantly features sand, usually augmented with bone and mica, which agrees with Caneva's (1991) description of the temper of her Dotted Wavy Line sherds, the Khartoum museum sherds are a bit more informative. Their paste features sand throughout, sometimes with mica but with the addition of quartz in all 27 Late Mesolithic sherds. Quartz is readily available within Jebel Moya. Six of the eight sherds from the Khartoum Museum with most types of wavy line décor (dotted, but not dashed wavy lines, and dragged wavy lines) and have sand paste with quartz, without mica; two are sand paste with quartz and mica, and are comb stamped dotted and dashed wavy lines. Unlike Caneva (1991), no lithic inclusions were observed.

The sherds range in thickness from a minimum of $0.46 \mathrm{~cm}$ to a maximum of $1.6 \mathrm{~cm}$. The different types of wavy line sherds range from $0.8-1.05 \mathrm{~cm}$, which correlates with Caneva's (1991) observations at the British Museum where dotted wavy line sherds ranged from $0.7-1.2 \mathrm{~cm}$. All the Late Mesolithic sherds observed at both museums were produced using the coiling technique. All the rims are simple and no lugs or handles have yet been found in the collections. Caneva (1991) stated that the British Museum impressed dotted wavy line décor was likely produced by cordwrapped sticks (dashes) and saw-toothed objects (dots); a 5-6 toothed comb produced the long dotted wavy lines, while a 9-10 toothed comb produced the short dotted wavy lines, according to 
Caneva. Brass' own observations from the Khartoum museum confirm rather that combs were used for both dotted and dashed décor. The three dotted way line sherds from the Khartoum museum can be further broken down as follows: one dotted rocker stamped long wavy lines, one rocker stamped dashed long wavy lines and one small-dashed stamped short wavy lines; all three were made using evenly serrated combs. Augmenting the variety in these two museum collections are the photographs published by Addison (1949) of select Mesolithic sherds from Wellcome's original excavations: Plate XCIV A1 shows short angular comb-stamped dotted wavy line, limited to near the rim, and Jesse (Jesse 2002) claims that these short angular waves are not yet known from elsewhere in Khartoum province, although incised examples are. Addison (1949: Plate XCIV C1) also has an example of a three-toothed comb dragged short wave, which is confirmed by the Khartoum museum's two sherds with short wave décor were done with a four-toothed dragged comb.

The newly examined national museum's late Mesolithic sherds demonstrate greater variability in décor and décor techniques than previously recognised either by the original excavators or the site report author (Addison 1949) or from the extant collections in the British and Petrie Museums (Brass 2016, Caneva 1991). With this new dataset, which will be augmented by future excavations at Jebel Moya down to bedrock, we confirm here the presence of short waves made by different combstamping, which are not known from an earlier time period in the central or south-central Sudan, but which were present earlier in the Sahara and in northern Sudan.

\section{Shaqadud - Site 21 and Midden}

Shaqadud is located ca. $50 \mathrm{~km}$ east of the Nile Valley in the Butana and $13 \mathrm{~km}$ east of the Meroitic locality of Naga. Found by Otto (Otto 1963: , 1964), it was the subject of intensive excavations by the southern Methodist University - University of Khartoum Butana Archaeological Project (Marks and Mohammed-Ali 1991, Marks et al. 1985). The term Shaqadud encompasses sites within a box canyon and on its rim to the south and east, and the basin:

1. S1-A: A wide cave at the back of the box canyon

2. S1-B: Midden within the canyon

3. S1-C: Shallow artefact distribution on the flat surface above the Cave

4. S21: A shallow artefact distribution a short distance to the east of the western rim

5. S1-D: A small site in the basin

In front of the cave is a small basin which is surrounded on the north by S1-B (15000 square metres, across the box canyon and $240 \mathrm{~m}$ out into it). Northwards, the deposits decrease from just over $3 \mathrm{~m}$ to ca. $20 \mathrm{~cm}$ due to erosion and deflation. (Marks et al. 1985). The initial single, Mesolithic, component occupation was at S21 with the single date bracketing 6430-6101 BC (Table 5); there are no non-Mesolithic deposits at S21 (Marks et al. 1985: 265). The earliest Mesolithic material in the S1-B Midden began shortly afterwards, with the earliest date from Layer 59 bracketed 6595 5376 BC and the date from Level 50 bracketing 6023 - 5562 BC (Marks 1991: Table 4.1). The latest dated level is Level 12 bracketed to $5511-4267$ BC, while Level 18 is between $4591-4268$ BC. The Cave is dated from ca. $2850-1700 \mathrm{BC}$.

\begin{tabular}{|l|l|l|l|l|l|}
\hline \multicolumn{1}{|c|}{ Period } & \multicolumn{1}{|c|}{ Site } & \multicolumn{1}{c|}{ Level } & $\begin{array}{c}\text { Uncalibrated } \\
\text { bp }\end{array}$ & Calibrated BC & Material \\
\hline $\begin{array}{l}\text { Post- } \\
\text { Khartoum } \\
\text { Neolithic }\end{array}$ & S1-A & 16 & $\begin{array}{l}3615 \pm 88 \\
\text { (SMU 1133) }\end{array}$ & $2271-1702$ & Charcoal \\
\hline & S1-A & 23 & $\begin{array}{l}3640 \pm 140 \\
\text { (SMU 1697) }\end{array}$ & $2458-1687$ & Charcoal \\
\hline
\end{tabular}




\begin{tabular}{|c|c|c|c|c|c|}
\hline & S1-A & 38 & $\begin{array}{l}4123 \pm 86 \\
(S M U 1128)\end{array}$ & $2891-2487$ & Charcoal \\
\hline & S1-A & 54 & $\begin{array}{l}4059 \pm 65 \\
(S M U 1127)\end{array}$ & $2871-2467$ & Charcoal \\
\hline & S1-A & 71 & $\begin{array}{l}4046 \pm 101 \\
\text { (SMU 1208) }\end{array}$ & $2884-2309$ & Charcoal \\
\hline & S1-D & TP 3, 14 & $\begin{array}{l}4120 \pm 120 \\
\text { (ETH 045- } \\
\text { 0447) }\end{array}$ & $3010-2341$ & Charcoal \\
\hline \multirow[t]{2}{*}{$\begin{array}{l}\text { Khartoum } \\
\text { Neolithic }\end{array}$} & S1-B & 12 & $\begin{array}{l}5,970 \text { B.P. } \pm \\
290 \text { (SMU } \\
1735)\end{array}$ & $5511-4267$ & Seeds \\
\hline & S1-B & 18 & $\begin{array}{l}\text { 5,584 B.P. } \pm 74 \\
\text { (SMU 1134) }\end{array}$ & $4591-4268$ & Seeds \\
\hline \multirow[t]{5}{*}{$\begin{array}{l}\text { Khartoum } \\
\text { Mesolithic }\end{array}$} & S1-B & 30 & $\begin{array}{l}5752 \pm 103 \\
(S M U 1287)\end{array}$ & $4829-4367$ & Charcoal \\
\hline & S1-B & 42 & $\begin{array}{l}7785 \pm 445 \\
(S M U 1736)\end{array}$ & $7786-5770$ & Charcoal \\
\hline & S1-B & 50 & $\begin{array}{l}6,893 \text { B.P. } \pm \\
131 \text { (SMU } \\
1186)\end{array}$ & $6023-5562$ & Seed \\
\hline & S1-B & 59 & $\begin{array}{l}7,056 \text { B.P. } \pm \\
321 \text { (SMU } \\
1290)\end{array}$ & $6595-5376$ & Charcoal \\
\hline & S21 & 6 & $\begin{array}{l}\text { 7,417 B.P. } \pm 67 \\
\text { (SMU 1310) }\end{array}$ & $6430-6101$ & Pila (shell) \\
\hline
\end{tabular}

Table 5. The published radiocarbon dates from Shaqadud, reproduced from Marks (Marks 1991: Table 4.1) re-calibrated at $95.4 \%$ confidence interval using the IntCal 13 calibration curve on OxCal 13.

There are 67 levels in the S1-B midden, with most levels defined as a $5 \mathrm{~cm}$ spit and 67 being the lower-most. Bedrock was reached at 3 metres below ground surface, with six excavated squares in the eastern half of the midden (Marks 1991: 43); there is deflation between midden and the southern half of the basin but the squares were positioned on the thickest and most undisturbed portion of the midden. Between the midden and the escarpment is a deep erosional channel starting on the escarpment (Marks 1991: 42). This stratigraphic sequence was said by the excavators to have shown, for the first time, the development between the Mesolithic and Neolithic periods in Central Sudan. The pottery was examined by Mohammed-Ali (1991) and Caneva (Caneva and Marks 1990) using different methodologies. Moahmmed-Ali used a seriation of motif and décor techniques, firing, hardness, temper and surface treatment to divide the ceramics into three wares: burnished fine, unburnished firable coarse and unburnished hard coarse. The wares were sub-divided by the ten traditionally defined motifs such as fish net, mat, etc. By contrast, Caneva employed her typological-based classificatory system, which she argued permitted identification of local pottery trends and the identification of new décor which may or may not have been the result of local innovation or outside influence, against the backdrop of a well-documented stratigraphy sequence.

Significant concerns have been raised about the integrity of the levels at S1-B, the reliability of the contextual association between the dated samples and the artefacts in those levels including the pottery, and the degree of intermixing of materials throughout the sequence (see Salvatori 2012: 441): 
1. Uncritical use of spits in drawing conclusions about material cultural patterning across and through undifferentiated deposits.

2. Formation processes in midden deposits lend themselves to vertical and horizontal movement, which can distort the analysis particularly if no stratigraphy can be discerned.

3. Levels 12 and 42 have a discrepancy in their radiocarbon dates, being older than the level immediately preceding it.

4. While Mesolithic pottery is present in the greatest numbers in the lower levels, some Mesolithic décor is also present throughout into the uppermost levels.

No micro-stratigraphy was discerned by the excavators. Marks (1991: 43) describes the sediments as largely "fine, powdery and unconsolidated". There were five sediments, labelled Layers A-D in descending order (Marks 1991:43-5, Figure 4.11):

- Layer A: Pebbles and gravel. Deflation had occurred.

- Layer B: Loose ashy soil. It was from ca. $20 \mathrm{~cm}$ until $80-85 \mathrm{~cm}$ below the surface.

- Layer C: Compact brown soil with less ash than in B but still a fair amount. It ended ca. $2.4 \mathrm{~m}$ below the surface.

- Layer D: Compact ashy soil. It extended until ca. $2.7 \mathrm{~m}$ below the surface.

- Layer E: Compact gravel and sand with sandstone fragments.

Marks et al. (1985: 267) further stated,

"It appears that the locus of occupation shifted from the top of the canyon [S21] to within it [S1-B], because as the deposits accumulated on the floor of the canyon, there was a marked increase in the amount of cultural items mixed in with them, particularly ceramics (Fig. 6). The presence of charcoal, delicate animal bones, and large conjoinable sherds together affirms that these cultural materials are in primary context. This occupation of the Khartoum Mesolithic type can be traced, without a break, through the lowest $1.10 \mathrm{~m}$ of the midden deposits. The ceramics, which are first seen sporadically at a depth of $3.10 \mathrm{~m}$ [below the datum], just above bedrock, reach a maximum density at a depth of 2.25-2.50 m and then thin out upwards until a new minimum density is reached at a depth of 1.75-2.00 m (Fig. 6)."

Moreover, Marks et al. (1985: 267) added, in defence of a consistent change in the nature of the pottery, that hard coarse ware occurs from the bedrock until $1.75 \mathrm{~m}$ below the surface with an overlap with friable coarse ware from c. $2.25 \mathrm{~m}$ below. The friable coarse ware continued throughout the remainder of the sequence and overlapped with fine ware which was present in increasing frequency from ca. $1.6 \mathrm{~m}$ below the surface. Mohammed-Ali's (1991: Fig. 5.13) report reinforces this point. However, the source of the accumulation of the sediment comprising these layers paints a more complicated picture.

The sediment derived from the top of the canyon to the east of the midden. The sandstone fragments in Layer $E$ come from the breakdown of the in-situ sandstone bedrock and were mixed with the colluvial sediment (Marks 1991: 44). The ash is believed by the excavators not to have a nature origin and because there are no signs of fireplaces within the excavated levels, a cultural origin from up on the escarpment is regarded as the most likely source. As such, Layers B and D were believed to be the result of secondary deposition. The same layers have a high artefact density. They state that the cultural materials in layers $\mathrm{C}$ and $\mathrm{E}$ are in primary context, and explain away the presence of ash in Layer $\mathrm{C}$ by invoking fireplaces outside of the excavated squares. However, the type and frequency of worked stone tools in Layer $C$ is similar to that of Layer $D$. The lowest $50 \mathrm{~cm}$ of sediment, which is Layer $\mathrm{E}$ and the bottom of Layer $\mathrm{D}$, has comparatively few stone tools (Marks and Mohammed-Ali 1991, Marks et al. 1985: 268). Apart from Layer D which contains $81.48 \%$ of all faunal remains from the midden (Peters 1991: Table 10.11), there is a distinct lack of faunal remains 
in the other layers. Peters (1991: 224) attributes it to "the destructive effect of slope water erosion, combined with a high sedimentation rate". Even so, Peters did not break it by spit level so a better understanding could be obtained about the relationship between faunal types and counts, and cultural materials like pottery and stone tools.

There is therefore much validity in Salvatori's criticisms. The increased faunal presence in Layer D was most probably the result of increased human activity on the east escarpment which was then washed downslope, while there is no concrete data in the published reports to substantiate the claim that layers $\mathrm{C}$ and $\mathrm{E}$ are primary and not secondary deposition. However, the radiocarbon dates are largely consistent with a continual accumulation of sediments; the two inconsistent dates are from levels 12 and 42, although no secondary sample was tested from either level and it is notable that the lower range of the calibrated dates overlaps with the calibrated range of the dated sample from the level directly above them. With each more sediment deposition, there may have been a small degree of reworking of deposits; the degree to which any human or animal burrowing may have affected the deposits is unknown. Taken together with the consistency in weathering of the faunal remains and the observable consistent changes in the types of pottery wares, there is a strong argument to be made for the overall integrity of the cultural materials from the midden in the excavated squares. There is one remaining poignant criticism though, namely the claim that Mesolithic décor is present in the upper levels, which is one of the questions posed in the below reexamination of select pottery sherds from S21 and S1-B.

\section{S21 and the Midden}

The entire pottery assemblages from the Joint University of Khartoum/Southern Methodist University Butana Archaeological Project's excavations of the Shaqadud sites was deposited at the British Museum. Unfortunately, most of the pottery boxes are unnumbered, rendering proper assignment of their contents to the correct site and temporal period problemmatic. Brass visited the British Museum in April 2017 in order to conduct a preliminary, highly selective re-examination of specific sherds. Brass requested all boxes marked in the British Museum's catalogue as containing Mesolithic sherds, regardless of them also containing Neolithic sherds or not: numbers $43-47$ (site S1-B) and 93 (site S21). Of the boxes requested, box 46 could not be located within a reasonable timeframe because of the sheer number of unmarked boxes.

I analysed a representative sample from Box 93 for S21. The S1-B boxes were divided up internally according to their original designated type. I also took a representative sample of sherds from each type in the latter:

1. Box 43 contains a mixture of Neolithic and Mesolithic sherds. Many levels represented are from the 30s. The lowermost represented is layer 55 and there are a few sherds from 54. Mohammed-Ali (1991) places level 25 as the transitionary level between the Mesolithic and Neolithic.

2. Box 44: Neolithic and Mesolithic: 3, 5, 10, 11, 12, 13, 21, 22, etc. Only Mesolithic 61 \& 67, 1 from 45 are present.

3. Box 45 . In the divide marked Type 14 is $I A-22(0.5 \mathrm{~cm}$ maximum and minimum thickness) and J8-31 $(0.7$ and $0.6 \mathrm{~cm})$, which both have rocker comb-stamped decor. However, the former is friable very coarse sand with quartz inclusions but no sign of mica. The latter is hard sand, lots of quartz and lots of mica. The former's temper is evident in Mesolithic sherds and the sherd is only slight thinner, which is currently believed to show a continuation of practice.

4. Box 47 contains S1-B and S1-D sherds. Most of the sherds are from layers attributed to the Neolithic. The sherd pieces are all tiny, with the maximum length of one Mesolithic sherd 
being $5 \mathrm{~cm}$. Many are ca. $3 \mathrm{~cm}$ in length. Only late Mesolithic layers 25 and 26 are present in this box.

Site 521

Surprisingly, the only descriptions of the pottery from this single component occupation site are limited statements that unburnished wavy line was present. Although limited, this is the first limited attempt to determine the variety within this middle Mesolithic assemblage. Thirteen sherds were analysed. All 13 are typically thin body sherds. The thinness ranges from 0.2 to $0.6 \mathrm{~cm}$ and the thickness $0.2-0.8 \mathrm{~cm}$. The paste is consistent: clay with quartz inclusions. There is no slipping or burnishing.

The décor is pretty varied even in this small sample (Figures 4, 5) (Table 6). Although there were only three tools (evenly and evenly serrated comb and stylus), there are 13 different types of motors actions. Overall, comb predominates. The most numerous of the motor actions is the dotted lines (23.08\%) produced by an evenly serrated two-pronged comb, inclusive of Alternately Pivoting Stamp (APS) banded lines. Evenly serrated combs were also used in producing long and short dragged comb wavy lines, comb stamped dotted wavy lines (long and short), banded lines of comb stamped dashes, and stamped lines of banded packed dots, continuous packed dashes, dashed wavy lines, overlapping dots and packed zigzag dots. The combs themselves were variable: one of the two dragged wavy lines (long) was produced by a comb with nine teeth, while two (banded packed dots as well as dotted lines inclusive of those produced using APS), three (banded lines of dashes) and four (packed zigzag dots) toothed combs were also discernible.
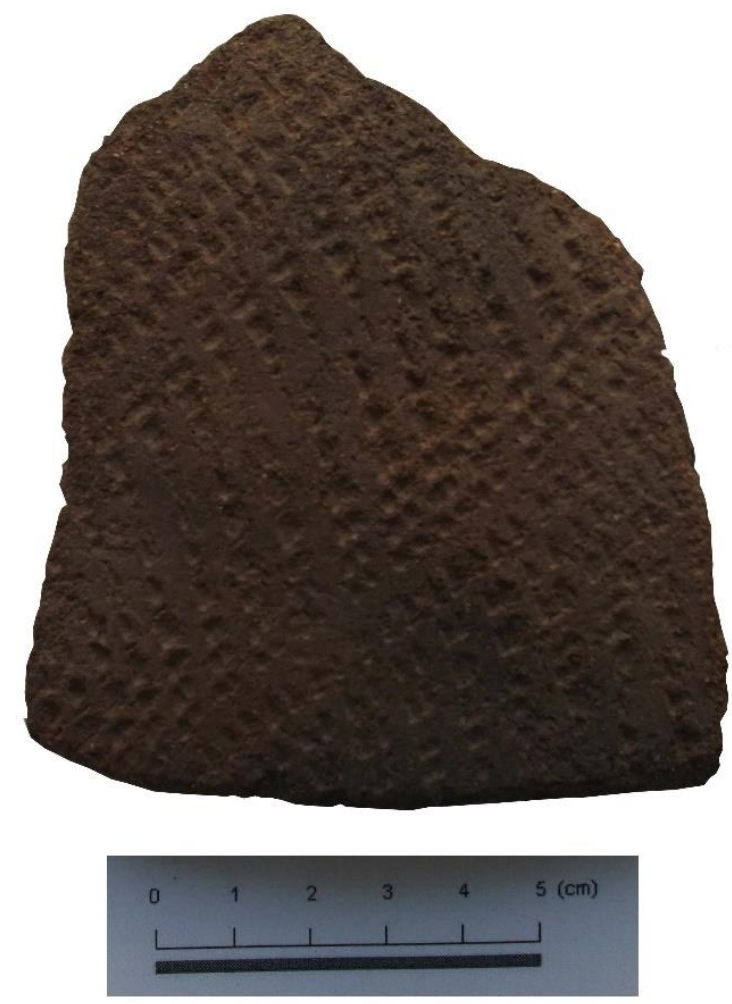

Figure 4. Shaqadud S21. Stamped comb lines (both evenly serrated dashes and plain dots, rocker. Banded. 3 toothed comb for former, 2 for latter) 

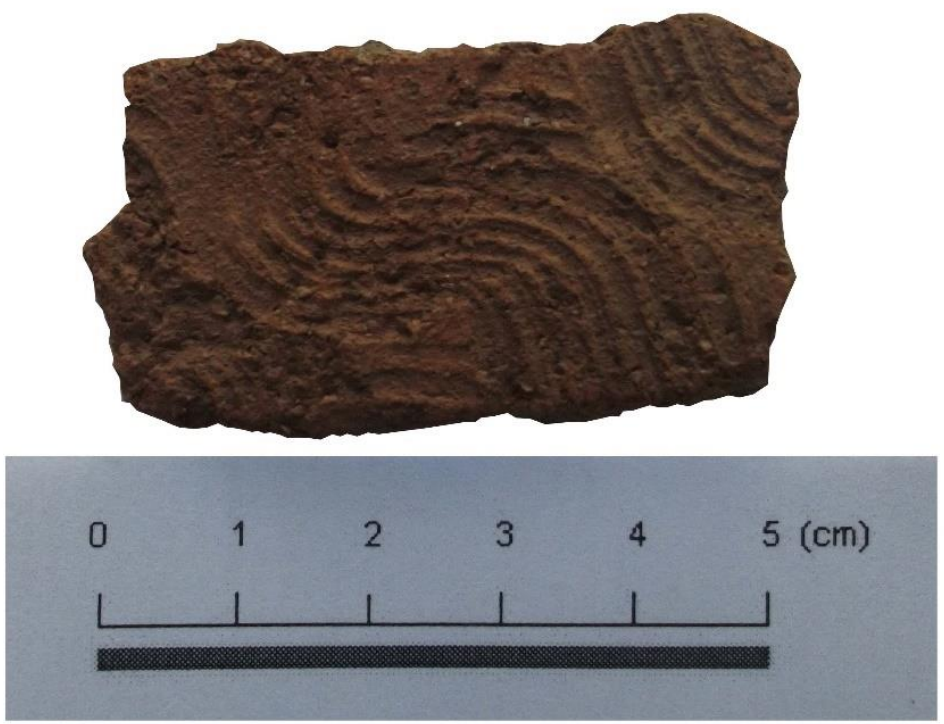

Figure 5. Shaqadud S21. Dragged comb wavy lines

\begin{tabular}{|l|l|c|}
\hline \multicolumn{1}{|c|}{ Tool } & \multicolumn{1}{|c|}{ Motor action } & S21 \\
\hline $\begin{array}{l}\text { Comb (evenly } \\
\text { serrated) }\end{array}$ & & \\
\hline & DRWL & $2(15.38 \%)$ \\
\hline & DRWL-S & $1(7.69 \%)$ \\
\hline & DTWL & $1(7.69 \%)$ \\
\hline & DTWL-S & $1(7.69 \%)$ \\
\hline & SL-BLD & $1(7.69 \%)$ \\
\hline & SL-BPD & $1(7.69 \%)$ \\
\hline & SL-CPD & $1(7.69 \%)$ \\
\hline & SL-D & $3(23.08 \%)$ \\
\hline & SL-DWL & $1(7.69 \%)$ \\
\hline & SL-OD & $1(7.69 \%)$ \\
\hline $\begin{array}{l}\text { Comb (unevenly } \\
\text { serrated) }\end{array}$ & SL-PZD & $2(15.38 \%)$ \\
\hline & & $1(7.69 \%)$ \\
\hline & SL-UD & $2(15.38 \%)$ \\
\hline Stylus & SL-UPZD & $1(7.69 \%)$ \\
\hline & & \\
\hline
\end{tabular}

Table 6. S21 body sherds: Single attribute occurrences of décor tools and the corresponding motor actions, and their percentage of occurrence on the sherds.

The motor actions employed with unevenly serrated combs are more limited. There are only two: stamped dotted lines and stamped lines with packed zigzag dots; the latter is in contrast to Jebel Moya a thousand years later when they were made using with evenly serrated combs. Finally, a stylus was used to produce one instance of dragged wavy lines. 


\section{Shaqadud Midden}

A total of 128 sherds were examined (Figures 6-8). Of these, 56 are from levels 30 and lower while 66 are from levels 1-29. At the right side of the bar chart are columns with more than one level number. These are broken sherds which fit back together. The three sherds from 10, 11 and 12, and 39 and 43 along indicate there was a small measure of vertical movement, though whether this was the result of post-depositional activities on the escarpment prior to being washed down or after the sediment was deposited below is unclear. More concerning is the re-fitting of a sherd from level 55 with sherds from levels 21 and 22, as well as one sherd from level 33 re-fitted to a sherd from level 42.
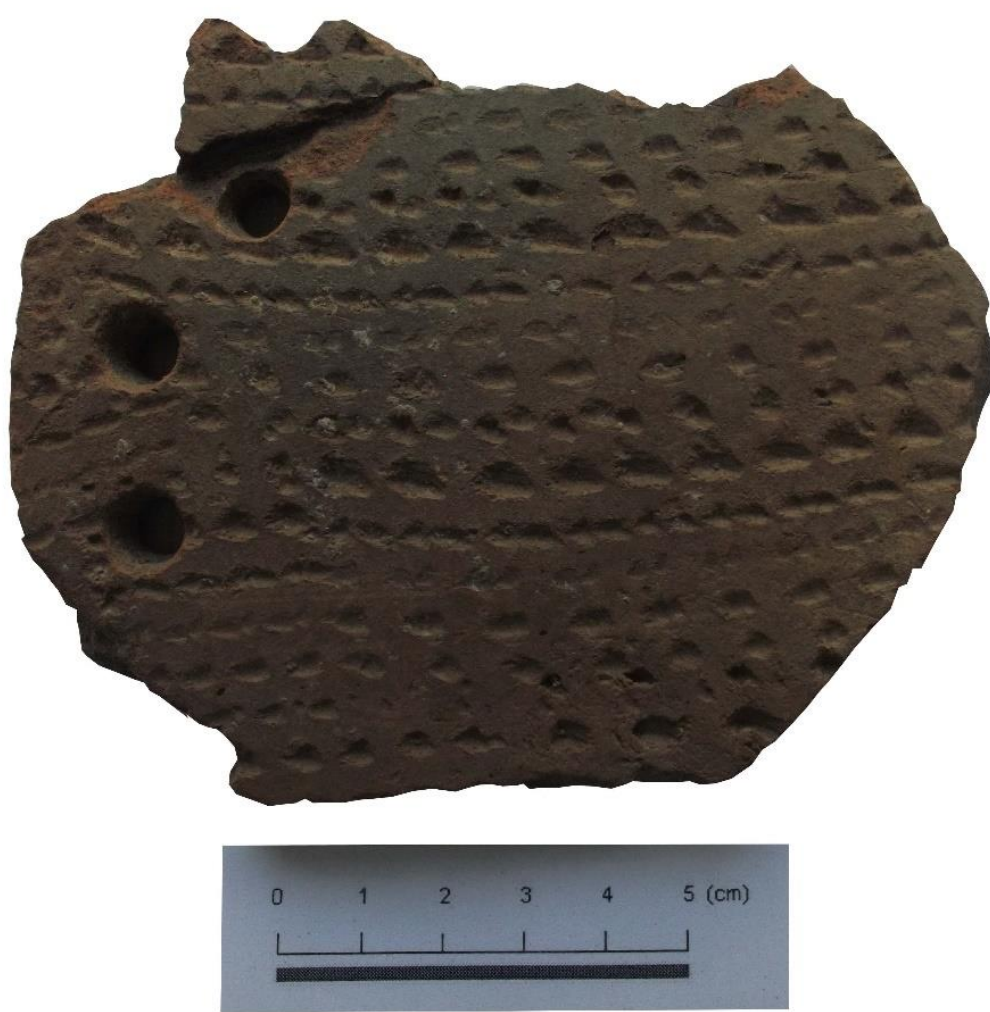

Figure 6. Shaqadud Midden, layer 28. Comb-stamped lines (rocker, dots, with a three-toothed, evenly serrated comb). 

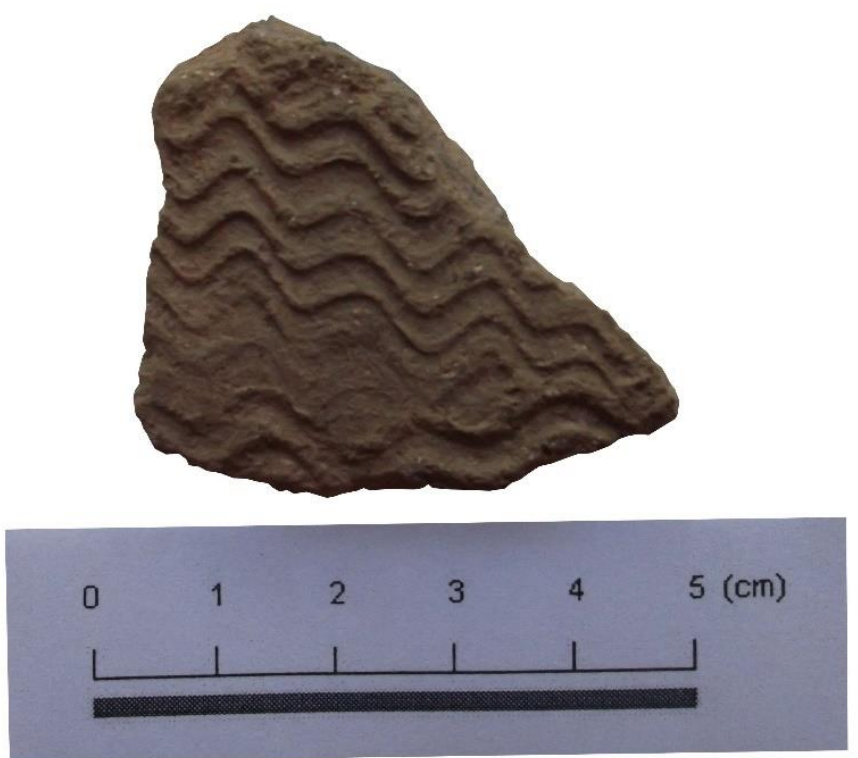

Figure 7. Shaqadud Midden, layer 63. Comb dragged wavy lines.

\section{Total}

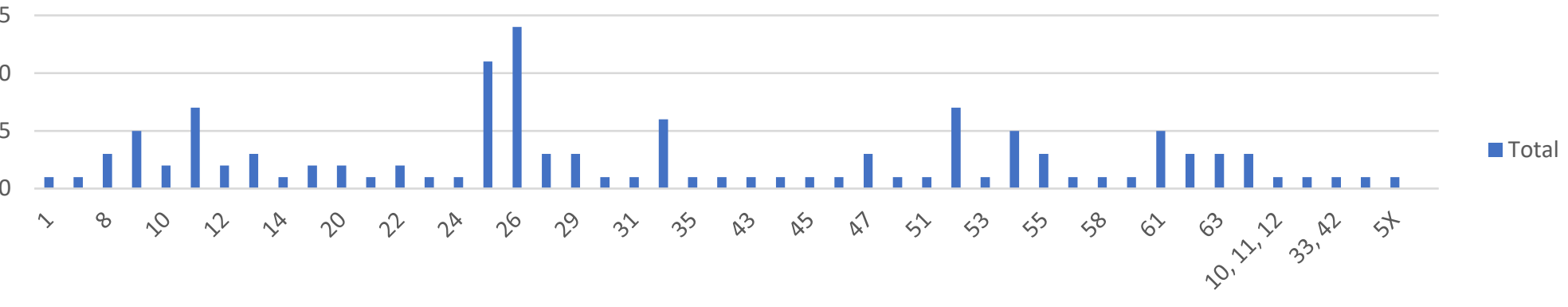

Figure 8. Shaqadud Midden: The number of sherds ( $Y$-axis) examined per level ( $X$-axis).

Mohammed-Ali (1991: Figure 5.13) displays the Hard Coarse Ware paste as continuing from the lowest levels up until level 37 , with the odd occurrence until level 25 . His analysis also concluded that is an overlap with Friable Coarse Ware which appears in about level 43 and continues throughout the remainder of the sequence, although it is overtaken in frequency by Fine Ware from level 18 upwards. Fine Ware first appears from level 30 upwards, although there is a solitary occurrence around level 33. However, his reconstruction of the distribution frequency of pastes can be challenged. Figure 9 shows the following patterns:

1. Hard Coarse Ware: It predominantly has quartz and mica inclusions. It is present in the earliest levels and continues down to level 25. It is in accordance with Mohammed-Ali's results.

2. Friable Coarse Ware: Large sand and grit with mica inclusions. Contra Mohammed-Ali (1991: Figure 5.13), there are occurrences of it from level 67, the earliest level, up until level 8.

3. Fine Ware: It has quartz inclusions and the occasional mica. It first occurs in level 58 and continues throughout the remainder of the sequence. 


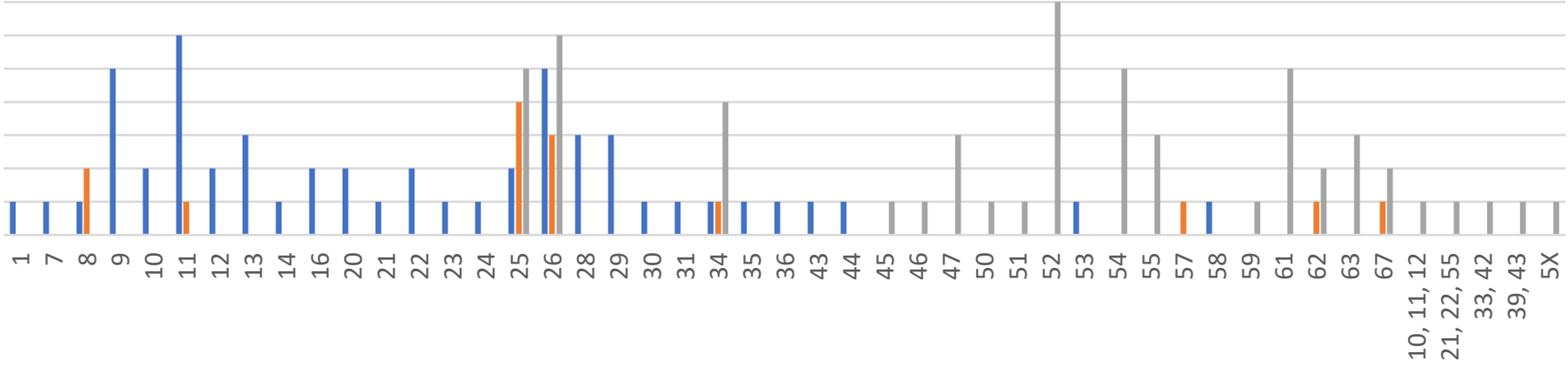

Figure 9. Shaqadud Midden. Count (Y-axis) of the different types of pastes examined per level (X-axis).

Although limited in number, the occurrences of Fine Ware in claimed pure Mesolithic levels than previously reconstructed argues for a degree of intermixing having occurred. By itself, the appearance of Friable Coarse Ware earlier in the Mesolithic levels than previously reconstructed could simply have been taken to mean that the frequency distribution of sherds comprised of its pastes needed to be re-examined, but it together with the new Fine Ware distribution pattern does lend weight to the hypothesis that there was undetected mixing of artefacts within and between the sediment deposits. It remains a defect of the original site report (Marks and Mohammed-Ali 1991) that the association between the dated samples and other nearby artefacts was not detailed. In lieu of the latter, we conducted single attribute analysis on the tools and motor actions present on the sherd bodies. Only two out of the 122 sherds had rims (straight and thin, everted and thin, with neither decorated) which made co-occurring attribute analysis impossible in this round of studies.

Of the 128 sherds, 96 have décor, all on the body. For the purposes of this initial re-examination of the Shaqadud ceramic assemblages, what is important is to is to see whether there are distinct Mesolithic and Neolithic assemblages which can be mapped in discrete stratigraphic units or whether there are clear signs of mixing having occurred.

Of the décor occurring in levels 50 and below, comb dragged wavy lines, comb dotted wavy line, stylus incised lines, stylus grooved lines and stylus dragged wavy lines do not occur from Mohammed-Ali's transitionary level 25 upwards. However, angular lines of comb stamped dashes, angular lines of banded comb stamped dashes, comb stamped dotted lines, lines of comb stamped packed zigzag dots, lines of square-toothed stamped comb, spaced lines of comb stamped dashes, comb stamped lines of spaced zigzag dots and triangular toothed comb stamped lines are found in levels above level 25 .

Caneva (1991: 21) stated, "Wavy Line has completely disappeared by level 44, while Dotted Wavy Line does not occur until level 38." The occurrences of different types of wavy line from this reexamination do not contradict her conclusion: The last dragged wavy line décor is in level 53, the two instances of dragged stylus wavy lines are from levels 55 and 63, while the singular occurrence of stylus incised wavy lines is from level 50 . However, the re-analysis of this small sample revealed one occurrence of comb stamped (dotted) wavy line in the early Mesolithic level 63.

Caneva (1991: 21) contradictory states both that "the alternately stamping technique [APS] is found only in [her pottery reconstructed] first two phases [levels $67-37$ ]" and, for her phase 4 (levels 516), "alternately pivoting stamp occurs only in its triangular varieties and especially with the smocking patterns". "Smocking" is defined as a "parallel set of types, obtained by making the tool pivot, for each pair of lines, in the dots/triangles of the last line impressed. The result is that the lines are perfectly parallel and equidistant from each other and each dot on a line falls between two dots 
of both the preceding and the following line, in a very regular smocking pattern. This technique was first described in a Saharan ceramic assemblage and called "return" technique (Caneva 1987a: 244)" (Caneva and Marks 1990: 19) In this re-examination, there is one instance of smocking in level 10. However, level 10 here has one instance of APS paired dashes. There are also three instances of APS paired dashes in straight banded lines from level 10 upwards and instances of rounded APS paired lines on three sherds from levels 10,11 and 12 which can be retrofitted together. The five instances of triangular tooth comb stamping in this re-examination are not APS; they occur in levels $54,16,11$ and 8.

Finally, Caneva (1991: 20) also stated, "A chronological sequence of assemblages with different dominant decorative techniques was observed from the bottom of the stratigraphy to the top: incision (wavy line), alternately pivoting stamp (pairs of dotted lines), and rocker." In order to make as direct a comparison as possible with Caneva's study, we will briefly make use of her four designated phases, with a minor adjustment to align with the units shown in Table 7:

1. Phase 1. Levels $67-56$. DRWL (dragged wavy lines), DTWL (dotted wavy line), SL-ADS (stamped lines, angular dashes), SL-S (stamped lines, square), S-WL (stylus-dragged wavy lines)

2. Phase 2. Levels $55-31$. DRWL (dragged wavy lines), SL-BLD (stamped lines, banded lines of dashes), SL-D (stamped lines, dotted), SL-PZD (stamped lines, packed zigzag dots), SL-S (stamped lines, square), SL-SD (stamped lines, spaced dashes), SL-SZD (stamped lines, spaced zigzag dots), SL-TT (stamped lines, triangular toothed), IL (incised lines), S-WL (stylus-dragged wavy lines), IF (impressed fingernails), IWL (incised wavy lines), SL-CPD (stamped lines, continuous packed dashes)

3. Phase 3. Levels $40-16$. SL-PZD (stamped lines, packed zigzag dots), SL-CPD (stamped lines, continuous packed dashes), IL (incised lines), SL-SD (stamped lines, spaced dashes), APS-PL (APS, dotted paired lines), APS-D (APS, paired dashes), SL-D (stamped lines, dotted), SL-PD (stamped lines, plain dashed), SL-UCPD (stamped lines, unevenly serrated continuous packed dashes), SL-USDS (stamped lines, unevenly serrated dots), IF (impressed fingernails), seed impressions, stylus scratchings, IV (incised Vs), SL-S (stamped lines, square), SL-BLD ((stamped lines, banded lines of dashes), SL-SZD (stamped lines, spaced zigzag dots), SL-TT (stamped lines, triangular toothed)

4. Phase 4. Levels $15-6$. APS-D (APS, paired dashes), APS-PDSB (APS, paired dashed straight banded), APS-PL (APS, dotted paired lines), APS-SM (APS, smocking), SL-ADS (stamped lines, angular dashes), SL-D (stamped lines, dotted), SL-DD (stamped line, dotted droplets), SL-PD (stamped lines, plain dashed), SL-PZD (stamped lines, packed zigzag dots), SL-S (stamped lines, square), SL-SD (stamped lines, spaced dashes), SL-SZD (stamped lines, spaced zigzag dots), SL-TT (stamped lines, triangular toothed), S-V (V-shape impressions, herringbone), SLUD (stamped lines, unevenly serrated dots), SL-USD (stamped lines, unevenly serrated dots), IV (incised Vs), S-IZ (incised zigzags)

The revised pattern emerging from this admittedly small sample is interesting. The finding of squaretoothed stamping in Phase 1 was unexpected; it appears again in phases 2 and 4, and it is on all pastes from hard coarse ware to friable coarse ware and fine ware. Comb stamped dotted wavy lines do not appear in the Phase 2, but this may be the result of the small sample as comb dragged, stylus dragged and stylus incised wavy lines appear in Phase 2. Comb stamped packed and spaced zigzag dots and continuous packed dashes (rocker technique) are also first seen in Phase 2, together with spaced dashes, triangular toothed comb stamping and impressed fingernails.

The dotted, dashed, dragged and incised wavy lines are not present in the third phase, but comb stamping continues and the use of APS is first evidenced together with plain dashed comb stamping. The first unevenly serrated comb décor also occurs, as do scratching made by a stylus, incised 
individual Vs, square toothed comb stamping and seed impressions. There are also more spaced décor motor actions.

In Phase 4, there is an increase in the use of the APS technique, which includes the first appearance of smocking, an impression seen much earlier in the central Sahara. There is the first herringbone and the use of stylus from the three preceding phases and both evenly serrated (phases 1-3) and unevenly serrated comb (Phase 3 ) continued.

While APS is not observed in either phases 1 or 2, contra Caneva (1991: 21), this could be an artefact of the smaller sample and there is a greater internal variety of different types of wavy lines than recognised by either Caneva (1991) or Mohammed-Ali (1990). What is not an artefact of sample size is the variety of APS in phases 3 and 4, which was unrecognised by either Caneva (1991) and Mohammed-Ali (1990). The APS primarily occurs on fine and friable coarse wares, while the retrofitted three sherds from levels 10,11 and 12 were hard coarse ware.

The number of comb teeth was determinable for seven different motor actions (SL-PZD, SL-D, SL-SZD, SL-CPD, SL-USD, DRWL and SL-BLD). There was no distinguishing feature. The number of teeth was consistently between 3-4 in this examined sample. Burnishing (Table 8 ) occurs in every grouping of levels, as does slipping (Table 9) with the exception of the lowest level (67) which is undecorated. However, there is a great number of sherds without slipping when the figures are broken down (Figures 10 and 11). Proportionally, fine decorated ware is more likely not to be slipped, while friable course ware has more slipping, as does the hard coarse ware. Comb dragged wavy line from levels 62-63 is, with one exception as well as an instance level 58 , unslipped; all are burnished. The median thickness of the sherds from throughout the levels is $0.6 \mathrm{~cm}$ and the thinness is $0.5 \mathrm{~cm}$.

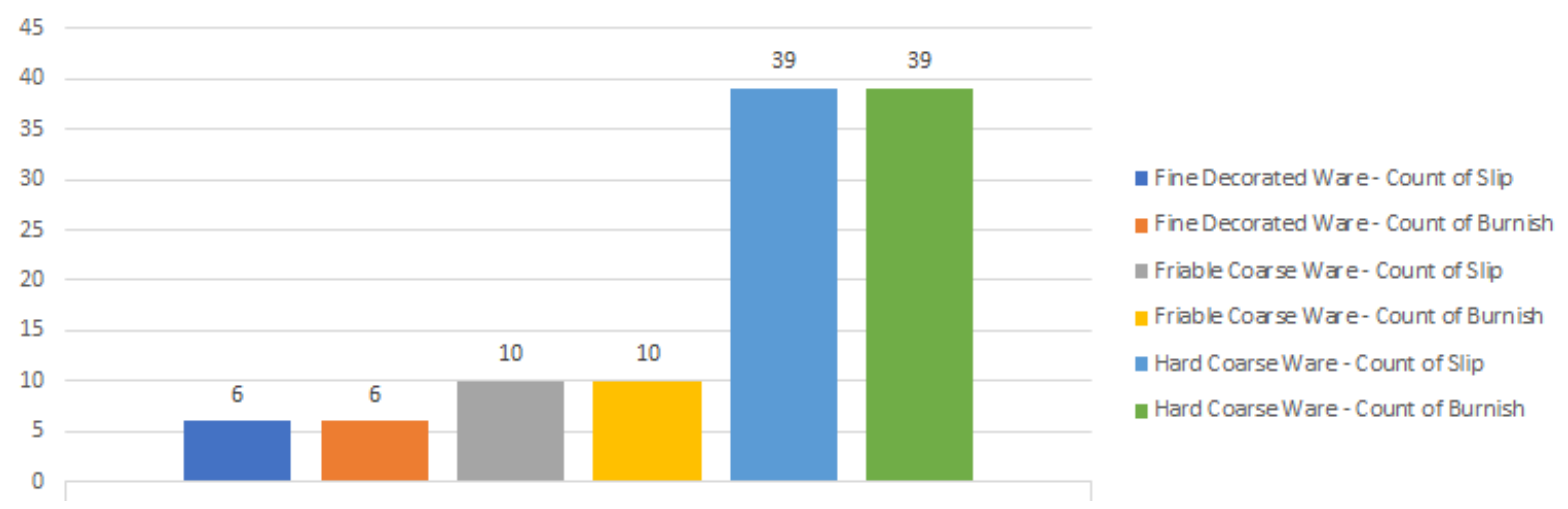

Figure 10. Occurrences of slipping and burnishing per ware. 


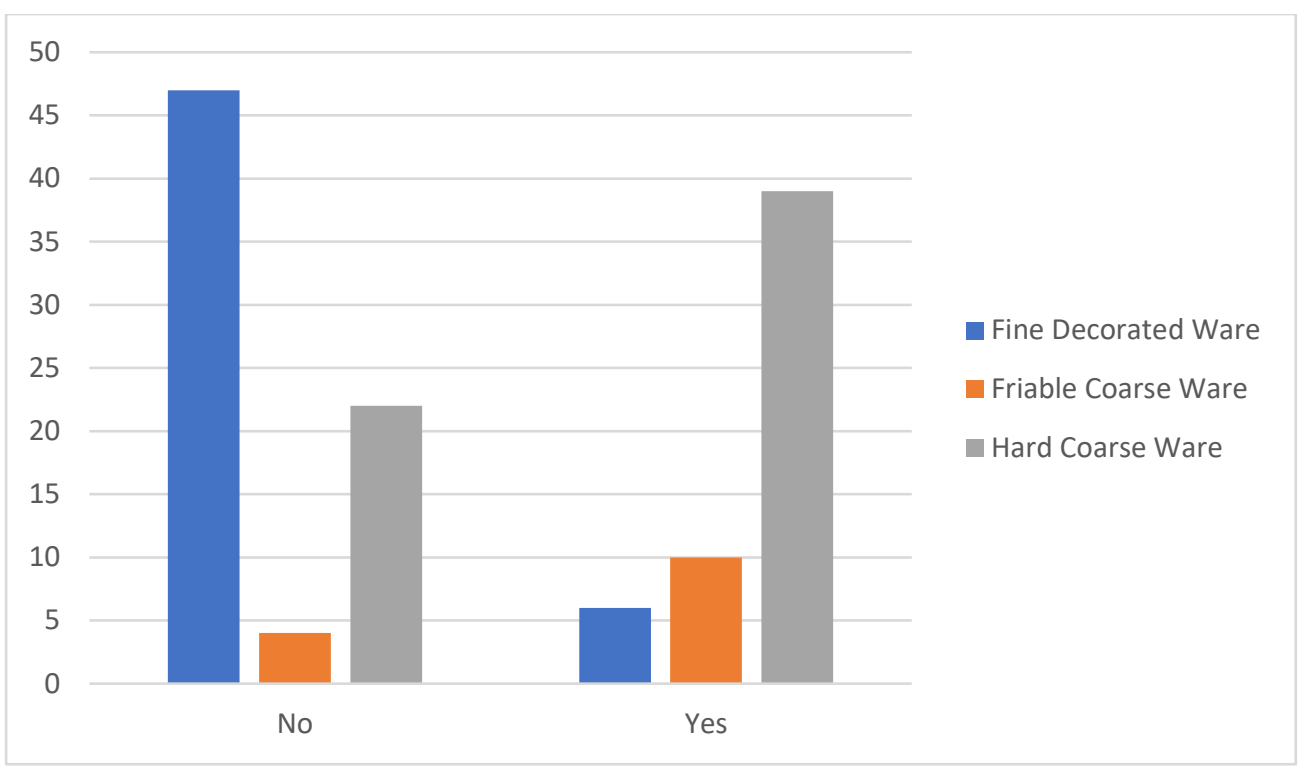

Figure 11. Difference occurrences of slipping per ware.

Based on the results displayed in Figure 9 for the paste distribution through the levels and Table 7 for the single attribute occurrences, there is an argument to be made for a small degree of intermixing of deposits. A working hypothesis is that this mixing, which appears to have occurred after the base levels of the midden were laid down as none of the base levels show signs of disturbance, may have occurred on the escarpment itself prior to successive deposits washed down into the basin. Such a hypothetical scenario would explain the relative consistency in the radiocarbon dates obtained from the levels, as well as the two dates which at first sight appear to be older than the date from the preceding levels but which in fact have a degree of overlap once calibrated. It would also explain the revised patterns seen in the re-examined sample of sherds from the British Museum. The questions raised over the validity of aspects of Caneva's description of the Shaqadud Midden pottery assemblages also pose a strong case for a comprehensive re-evaluation of a much larger sample of the pottery assemblages curated at the British Museum.

Such a re-evaluation, using single and co-occurring attribute analyses, would go a long way towards resolving these questions regarding the composition and distributional nature of the overall assemblage, and whether, as is advocated by the authors here, the radiocarbon dates are still to be taken as a reasonable chronometric guideline for dating the excavated portion of the midden deposit. Additional radiometric dates would also not go amiss. Such a wide-ranging comprehensive re-examination would also confirm or revise Caneva's claim of short Dotted Wavy Line motifs occurring only in the late Mesolithic levels (see Marks \& Mohammed-Ali 1991: 71, Fig. 5-3a), at the turn of the $5^{\text {th }}$ millennium $B C$, which she hypothesised represents a period of contact with incoming Saharan pastoralists from whom the later smocking technique was also borrowed. 


\begin{tabular}{|c|c|c|c|c|c|c|c|c|c|c|c|c|c|c|c|}
\hline Tool & $\begin{array}{l}\text { Motor } \\
\text { action }\end{array}$ & $1-5$ & $6-10$ & $11-15$ & $16-20$ & $21-25$ & $26-30$ & $31-35$ & $36-40$ & 41-45 & $46-50$ & $51-55$ & $56-60$ & $5 X$ & $\begin{array}{l}61- \\
63 \\
\end{array}$ \\
\hline \multicolumn{16}{|l|}{ Chaff } \\
\hline & Markings & & & & & & & & & & 2 & 2 & & & \\
\hline \multicolumn{16}{|l|}{$\begin{array}{l}\text { Comb } \\
\text { (evenly } \\
\text { serrated) }\end{array}$} \\
\hline & APS-D & & 1 & & & 1 & & & & & & & & & \\
\hline & APS-PDSB & 1 & 2 & & & & & & & & & & & & \\
\hline & APS-PL & & 1 & 2 & & 1 & 2 & & & & & & & & \\
\hline & APS-SM & & 1 & & & & & & & & & & & & \\
\hline & DH & & & 1 & & & & & & & & & & & \\
\hline & DRWL & & & & & & & & & & & 1 & 1 & & 4 \\
\hline & DTWL & & & & & & & & & & & & & & 1 \\
\hline & SL-ADS & 1 & 2 & 2 & & & & & & & & & 1 & & \\
\hline & SL-BLD & & & & & 2 & & & & & & 1 & & & \\
\hline & SL-CPD & & & & 1 & 4 & 3 & 2 & & 1 & & & & & \\
\hline & SL-D & & 2 & 4 & & 1 & 1 & & & & & 1 & & & \\
\hline & SL-DD & & & 2 & & & & & & & & & & & \\
\hline & SL-PD & & 1 & & 1 & & 1 & & & & & & & & \\
\hline & SL-PZD & & 1 & 1 & 1 & & 2 & 2 & 1 & & & 3 & & & \\
\hline & SL-S & 1 & 1 & & 1 & 1 & & & & & & 1 & & 1 & 2 \\
\hline & SL- SD & & & 2 & & & & & 1 & 1 & & 2 & & & \\
\hline & SL-SZD & & & 3 & 1 & & & & & & & 1 & & & \\
\hline & SL-TT & & 2 & 2 & 1 & & & & & & & 1 & & & \\
\hline & S-V & & 1 & 2 & & & & & & & & & & & \\
\hline \multicolumn{16}{|l|}{$\begin{array}{l}\text { Comb } \\
\text { (unevenly } \\
\text { serrated) }\end{array}$} \\
\hline & SL-UCPD & & & & & & 2 & & & & & & & & \\
\hline & SL-UD & 1 & 1 & & & & & & & & & & & & \\
\hline & SL-USDS & & & 1 & & & 2 & & & & & & & & \\
\hline
\end{tabular}




\begin{tabular}{|c|c|c|c|c|c|c|c|c|c|c|c|c|c|c|c|}
\hline & & $1-5$ & $6-10$ & 11-15 & $16-20$ & $21-25$ & $26-30$ & $31-35$ & $36-40$ & 41-45 & $46-50$ & 51-55 & $56-60$ & $5 X$ & $\begin{array}{l}61 \\
63\end{array}$ \\
\hline \multicolumn{16}{|c|}{ Fingernail } \\
\hline & IF & & & & & & 1 & & & 2 & 1 & & & & \\
\hline \multicolumn{16}{|l|}{ Seed } \\
\hline & Impressions & & & & & & 1 & & & & & & & & \\
\hline \multicolumn{16}{|l|}{ Stylus } \\
\hline & IL & & & & & & & 1 & & & & 1 & & & \\
\hline & IV & & 1 & & & 1 & & & & & & & & & \\
\hline & IWL & & & & & & & & & & 1 & & & & \\
\hline & S-GL & & & & & & & & & & & & & 1 & \\
\hline & S-IZ & & & 1 & & & & & & & & & & & \\
\hline & S-WL & & & & & & & & & & & 1 & & & 1 \\
\hline & Scratchings & & & & & 4 & 3 & & & & & & & & \\
\hline
\end{tabular}

Table 7. Shaqadud Midden: Single attribute occurrences of motor actions through the sequence in groups of 5 levels. 


\begin{tabular}{|l|l|l|}
\hline Levels & No & Yes \\
\hline 67 & & 3 \\
\hline $11-15$ & & 15 \\
\hline $1-5$ & & 1 \\
\hline $16-20$ & & 4 \\
\hline $21-25$ & & 18 \\
\hline $26-30$ & & 21 \\
\hline $31-35$ & & 9 \\
\hline $36-40$ & & 2 \\
\hline $41-45$ & & 5 \\
\hline $46-50$ & & 5 \\
\hline $51-55$ & & 18 \\
\hline $56-60$ & 1 & 2 \\
\hline $5 X$ & & 1 \\
\hline $6-10$ & 1 & 11 \\
\hline $61-63$ & & 11 \\
\hline Total & $\mathbf{2}$ & $\mathbf{1 2 6}$ \\
\hline
\end{tabular}

Table 8. Occurrences of burnishing through the sequence in groups of 5 levels, with percentage occurrence

\begin{tabular}{|l|l|l|}
\hline Levels & No & Yes \\
\hline 67 & & 3 \\
\hline $11-15$ & 14 & 1 \\
\hline $1-5$ & 1 & \\
\hline $16-20$ & 4 & \\
\hline $21-25$ & 8 & 10 \\
\hline $26-30$ & 10 & 11 \\
\hline $31-35$ & 4 & 5 \\
\hline $36-40$ & 2 & \\
\hline $41-45$ & 4 & 1 \\
\hline $46-50$ & 1 & 4 \\
\hline $51-55$ & 6 & 12 \\
\hline $56-60$ & 1 & 2 \\
\hline $5 X$ & 1 & \\
\hline $6-10$ & 12 & \\
\hline $61-63$ & 5 & 6 \\
\hline Grand Total & $\mathbf{7 3}$ & $\mathbf{5 5}$ \\
\hline
\end{tabular}

Table 9. Occurrences of slipping through the sequence in groups of 5 levels. 
Sorourab 2 at the end of the $10^{\text {th }}$ millennium BC (Figure 2, Table 10). The dates from the Atbara cluster in the $8^{\text {th }}$ millennium BC. Most of the early dates for central Sudan are from the $7^{\text {th }}$ and $6^{\text {th }}$ millennia BC.

\begin{tabular}{|l|c|c|}
\hline \multicolumn{1}{|c|}{ Site } & Uncalibrated bp & Calibrated BC \\
\hline Amekni (Algeria) & $8050 \pm 80$ & $7288-6690$ \\
\hline Site Launey (Algeria) & $8475 \pm 100$ & $7735-7198$ \\
\hline Timidouin, TF-TD 155-32 (Algeria) & $8100 \pm 130$ & $7455-6685$ \\
\hline Gabrong (Chad) & $8560 \pm 120$ & $8164-7327$ \\
\hline Bir Kiseiba E-80- 1 (Egypt) & $8020 \pm 90$ & $7181-6652$ \\
\hline Fozzigiaren (Libya) & $8072 \pm 100$ & $7325-6691$ \\
\hline Ti-n-Torha East (Libya) & $8640 \pm 70$ & $7936-7546$ \\
\hline Uan Afuda (Libya) & $8765 \pm 105$ & $8207-7598$ \\
\hline Adrar Bous 10 (Niger) & $9130 \pm 65$ & $8542-8247$ \\
\hline Tagalagal (Niger) & $9370 \pm 130$ & $9134-8300$ \\
\hline Abu Darbein (Sudan) & $8640 \pm 120$ & $8198-7491$ \\
\hline Aneibis (Sudan) & $8230 \pm 120$ & $7553-6841$ \\
\hline El Damer (Sudan) & $8390 \pm 50$ & $7567-7342$ \\
\hline Sorourab 2 (Sudan) & $9370 \pm 110$ & $9121-8311$ \\
\hline Al Khiday (Sudan) & $7980 \pm 40$ & $7050-6707$ \\
\hline
\end{tabular}

Table. Early DWL dates in the Sahara and Sudan. From Barich (1987), Barich et al. (1984), Camps (1969), Camps et al. (1973), Close et al. (1984), Di Lernia (1999), Gabriel (1981), Haaland and Magid (1992, 1995), Khabir (1987), Roset (1996), Schuck (1989).

So-called incised wavy line (IWL) is infrequent in the Sahara but it is frequent in the Nile Valley (see also (Usai 2004)), as originally hypothesised by Arkell (Arkell 1962). IWL is not present in the Central Sahara; it is present in a band between northern Chad and the Red Sea (Jesse 2003). The oldest IWL dates to Sorourab 2 in the Nile Valley and perhaps also Wadi el Akhdar 82/83 (Gilf Kebir), although Jesse (Jesse 2010) points out that there is a $7^{\text {th }}$ millennium uncalibrated bp date on another sherd of the same ware (Gehlen et al. 2002: 111, Table 111). Amongst Arkell's (1949) Plates on pottery from Khartoum Hospital are depictions of small stylus-incised waves (Plate 68). Unfortunately, the chronological sequence cannot be adequately reconstructed and there is not enough data to undertake attribute analyses using published sources. Similar wavy line types are also present at Saggai (Caneva 1983).

By contrast, dotted wavy line (DWL), as traditionally defined, is seen across much of the Sahara and into the Nile Valley from the $9^{\text {th }}$ millennium BC onwards. Differences in the length of the waves has attracted interest. Lengths averaging $2-4 \mathrm{~cm}$ are commonly found in the eastern Sahara and the Nile Valley. Short waves, ca. $0.7-0.8 \mathrm{~cm}$, have been illustrated and briefly described in central Saharan and northern Chad assemblages, and more recently in select assemblages from the Sudan. The earliest known short wave DWL is at Tagalagal in Niger (Roset 1987). Other early and common Sahara décor includes rocker comb stamped packed zigzags. In the Central Sudan, Plate 70:1 in Arkell (1949) depicts small dotted wavy lines made by comb stamping.

At Shabona on the White Nile, dated to the $7^{\text {th }}$ and early $6^{\text {th }}$ millennia $B C$ on the basis of two radiocarbon dates of $7027-5886 \mathrm{BC}$ and $6028-5715 \mathrm{BC}$ respectively, incised and dotted wavy line is present but none of the waves are short (Clark 1989). The décor was made using straight or convex combs, cord element, twisted cord, stamped (including plain stamping, pivoted and rocker), dragged combing and "jab and drag". Usai (2004) has argued for diffusion of late Mesolithic pottery only from south of the Atbai through the Bayuda or along the Nile to Wadi Howar. 
Hatim el Nour (pers. comm. 2012) conducted an archaeological survey in the lower White Nile valley and found ca. 30 sites with materials from different periods. The temper of the wavy line sherds includes crushed shell, unlike at Jebel Moya. The photos shared with Brass include comb-dragged wavy lines with and without comb-stamped lines on the same sherd, and stylus-incised wavy lines. It is not known if any forms of dotted wavy line were found.

As valuable as these dates are, there are issues. Most Central Sudan Mesolithic occupation localities were

"excavated using artificial horizontal cuts because of the lack of discrete features and distinct deposition layers but, with the exception of an attempt made by Caneva et al. (Caneva 1993), no one sought to define a strategic approach to understand the negative postdepositional effects due to Meroitic and Post-Meroitic practices of using prehistoric sites as tumulus-like grave fields... In most cases, thickness of the deposit can only be related to redeposition phenomena and not to a coherent stratification of more or less continuous site frequentation" (Salvatori 2012: 402-403)

The site of Rabak along the White Nile, south-west of Jebel Moya, is an example of the issues identified by Salvatori (2012). Rabak is important because it is only the third site in the southern Gezira with pre-Meroitic deposits that were believed to be in-situ. Rabak was excavated between February and March 1983. The cultural deposit measured $200 \times 80 \mathrm{~m}$ but surface materials were present over a larger area and Mousterian tools were on the surface, although none were in the $18 \mathrm{~m}^{2}$ excavated deposit (el Mahi and Haaland 1984). This raises questions about the integrity of the stratigraphic sequences. Three dates were obtained from shell, though Brass (2016) has raised objections based on the freshwater effect which is reinforced by level $6(50-60 \mathrm{~cm}$ deep, $6020+/-130$ bp $5293-4615 \mathrm{BC}$ ) having the same radiocarbon age as level 15 (140-150cm deep, 6050 +/- 100 $5219-4722 \mathrm{BC}$ ), which could be due to different intensity of occupation but then a question must be raised as to why there was no recognisable change in soil colour or other differential marker between level 6 and level 2 (4490 +/- 100bp, 3498 - 2909 BC). Haaland (Haaland 1984: 44) mentions that an unspecified number of cattle bones were found in Level 9 . However, in a nutshell, the published chronology is unreliable. However, there are both wavy line sherds (unspecified) and sherds similar to the Khartoum Neolithic (el Mahi and Haaland 1984: Figs. 2a \& b). Haaland \{Haaland, 1984 \#10183) claims that the early Neolithic pottery at Rabak was made using fish spines and are burnished; however not all tools were correctly identified. For example, Figure 2a in \{el Mahi, 1984 $\# 10550$ ) is rocker-stamped décor with an evenly serrated comb, while $2 \mathrm{~b}$ are APS "droplets" and evenly serrated comb dashes. Both are banded early Neolithic.

Salvatori and Usai have been conducting meticulous excavations at Al Khiday, south of Khartoum, which address these issues (Salvatori et al. 2011, Salvatori 2012). Site 16-D-5 was first occupied at the start of the $7^{\text {th }}$ millennium BC and continues for approximately three quarters of a millennium. Incised wavy line and stamped dotted wavy line are present from the beginning, while APS appears towards the end of the sequence. The DWL evolves from classic comb-stamped to a combined "dashdot" in the latter half (Salvatori 2012). The nearby site of $10-W-4$, dating from the late $6^{\text {th }}$ millennium BC, also has DWL but it is short dotted wavy line (Salvatori 2012: Fig. 29). The pottery from 10-W-4 is rarely burnished, had temper comprised of feldspar and quartz grains with angular edges alone or mixed with sand, and was made using the coiling technique. It is hypothesised that it was a seasonal camp due to increasing mobility caused by increasing climatic deterioration from the early $6^{\text {th }}$ millennium BC onwards both there and in the eastern Sahara (Adamson et al. 1982: ,Kuper and Kröpelin 2006: ,Manning and Timpson 2014: , 2015: ,Nicoll 2004: ,Salvatori 2012).

While burnished ware has been associated with pastoral peoples in the central Nile Valley and in the Atbai, from the $5^{\text {th }}$ millennium BC onwards (Caneva 1993), the presence of burnishing at Shaqadud, 
where pastoralist activity has not yet been detected. Smocking, or the "return" technique, is widespread in the mid-Holocene of the central Libyan Sahara, for example from the start of the fourth millennium BC at Uan Muhuggiag (Caneva 1987a) when pastoralism was well established. It is largely absent from the Nile Valley. There are documented instances at EI Ushara (Shendi Province) and, from Caneva's examination, at Shaqadud Midden, especially levels 5-20 which places it in the mid-late $5^{\text {th }}$ millennium BC.

There are shifts seen between late Mesolithic and early Neolithic assemblages. The Early Neolithic sites in the Central Sudan include Urn Direiwa I level 1 (5207 - 4714 BC), Kadero I level 1 (4770 4350 BC), Shaheinab level 5 (4727 - 4368 BC) and Zakiab level 2 (5198 - 4623 BC) (Haaland 1984). There was multiple resource exploitation. The dominant components were cultivation, animal husbandry, and fishing, but the importance of the different resources would vary according to season. The Neolithic pottery from Shaheinab was, like Jebel Moya's late Mesolithic sherds, also shaped by coiling but it was finished off using an anvil and paddle, contra Jebel Moya and Shaqadud Midden. It was burnished, as is characteristic of other Neolithic assemblages in central Sudan such as at El Geili. There are no wavy lines and only a small percentage $(2.7 \%)$ of dotted wavy line. Coarse ware is present. The motifs include stylus incised lines, triangular comb toothed stamp, comb stamped lines and comb stamped zigzags (Arkell 1953: Figs. 6.14-16.15, Plate 16.19). It is a range of motor actions and décor which has similarities to El Geili (Caneva 1988).

The Mesolithic dotted wavy line décor, especially curved, was produced by tools (combs and cat fish spines) with 4-7 teeth. At Neolithic Esh Shaheinab and El Geili (Arkell 1953: ,Caneva 1988), the typical plain (not rocker)-stamped DWL was produced using a two-toothed comb; the curves have a small arch, the length of which is $5-10 \mathrm{~mm}$, meaning some of them are small wave DWL (see (Caneva 1988: Figs. 12.13-14,17 and 20.12b). It is either the only or combination with impression rows (also two teeth). Short DWL is also clearly present at Saggai (Mohammed-Ali and Khabir 2003: 38, Figs. 32 (3231) (e-f)).

Indeed, the presence of the latter Saharan décor element as well as the greater mobility of populations at this time which would have resulted in greater intra-group and intra-cultural contact and exchanges, shows that we are only at the beginning of understanding the dynamics of the reconfiguration of the socio-political, ideological and economic landscapes of this important region of North-East Africa. This is a time separate from the start of the Kerma periods up to 2500 years later, and it is poignant also to understand what was occurring further north along the Nile Valley in what is known as Nubia, in addition to the Sahara.

\section{Upper and Lower Nubia}

The Mesolithic at El-Barga, 15km east of Kerma, has DWL but no IWL. The earliest radiocarbon date places the start of occupational activity to between ca. 7567-7195 BC; this is later than the Kerma region more broadly where the Mesolithic begins ca. 8300 BC (Honegger 2014). The Neolithic begins at ca. $6048-5766$ BC, which is earlier than in the Central Sudan. As at Shaqadud, comb stamped DWL continues down into the Neolithic. APS characterises the El-Barga pottery and no parallel is known except in the Acacus region (central Libyan Sahara), where it dates to the pastoral periods

Although the Mesolithic at nearby Wadi el-Arab begins ca. 8300 BC, DWL first appears in Honegger's Mesolithic III $(7200-6300 \mathrm{BC})$ in conjunction with sherds with a pattern that has been termed "stem and leaf" (Gatto 2002b: Figure 5.2). Gatto (Gatto 2013) believes that there are similarities between this pattern of pottery and the El Nabta phase pottery at Nabta Playa (Eastern Sahara, Egypt). The "stem and leaf" is disjointed with a gap between the "top" of each side. There are also incised vertical lines on a rim, incised horizontal lines (not a comb as there is no pattern of repeated even 
spacing), comb-stamped wavy lines (arch-shaped), dashed comb and stylus incised \& infilled banded lines. Mesolithic IV (6300-6000 BC) has similarities with Nabta Playa's El Jerar. The first burnished pottery is associated though with Neolithic I at El-Barga II (6000-5500 BC) and it is currently believed to have no comparative assemblage from that time period in Nubia.

Early earliest burnished black-topped and ripple ware appears at broadly the same time in the region at el-Barga and Karuka during the $5^{\text {th }}$ millennium BC; similar characteristics are also present on Badarian and Abkan pottery (Honegger 2004). By this time, these were communities with a significant pastoral component. While there was what Honegger has termed a "Proto-pastoral phase" in the Kerma region and evidence for early Near Eastern cereals has also been found in Upper Nubia (Madella et al. 2014), there is no evidence for this in the Central Sudan where there was a comparatively quick transition from a hunter-gatherer-fisher way of life to the incorporation of livestock resulting from either adoption or population movement, or both.

DWL is also present in the Second Cataract region, on two variants of fabric, and is chronologically between ca. 7000 - 4900 BC. Gatto (Gatto 2006) states that Khartoum Variant-like sherds are present at Khartoum Hospital (Arkell's atypical sherds) and in the Atbai-Nile area, but no thorough examination has been undertaken to verify and quantify. Meanwhile, long wave DWL is present in the Wadi Howar from ca. 5200 BC, but not short waves (Jesse 2004). Indeed, it has been proposed that the Khartoum Variant and the Early Khartoum of the central Nile Valley developed simultaneously but distinct (Garcea and Hildebrand 2009). The earliest C14 dates for Sai Island are ca. 7600 BC. At Site 8-8-10C, Sai Island, the length of the dotted wavy lines, which appear from Level 2 and which comprise $11.3 \%$ of the assemblage, ranges from $7-11 \mathrm{~mm}$, with an average of $9.4 \mathrm{~mm}$ (D'Ercole 2017: 44, 46, 83). The combs had two to three teeth. Short DWL is also present at the lower portion of Level 6 at site Abka IX (8291-6396 BC)(Gatto 2006), which is over a thousand years before its first presence at Jebel Moya and Shaqadud to the south, and no known site with this décor yet bridges this temporal gap.

The appearance of the APS technique cannot be taken as an indicator of herding in the broader Nile Valley, contra the central Sahara, which is borne out by its presence at Shaqadud. At neither Jebel Moya or Shaqadud has ripple or burnished black-topped ware been found. While the presence of ripple ware in the Atbai shows there would have been exchange and contact to some degree between it and Nubia (Winchell 2013), it appears that while there would have been awareness of different décor techniques and motifs between neighbouring groups and those further afield, there were distinct differences between the pottery of Central Sudan and Nubia which would have been the result of conscious decisions made by the potters.

\section{Sahara}

The earliest pottery locals cluster in the southern Sahara and at Oujougou, Mali, which is the western and southern-most evidence of early pottery slightly pre-dating ca. 9200 BC (Huysecom et al. 2009). So-called dotted wavy line is present from the $8^{\text {th }}$ millennium BC in the Sahara. Haaland (1992) hypothesised that DWL spread into the Sahara from the Nile Valley through expansion during the reoccupation of the Sahara, a view backed up as late as 2004 by Garcea (2004). However, Jesse (2010: 232) correctly remarks that wavy lines never constitute the majority of the décor and states that it should thus be regarded as a cultural marker with regional differentiation.

Short wave DWL $(0.7-0.8 \mathrm{~cm}$ ) is present in the Ennedi and in the Tibesti (Gabriel 1977: 85, No. 84). In the Ennedi, Northern Chad (e.g. Délébo), short wave DWL came after incised wavy line and long wave DWL $\left(2-4 \mathrm{~cm}\right.$ ) (Bailloud 1969). The earliest presence is from the $9^{\text {th }}$ millennium BC at Tagalagal (Roset 1996), broadly contemporary with the first appearance in the Nile Valley at Sourab 2 (Khabir 1987) and in the $8^{\text {th }}$ millennium BC at Abu Darbein and Aneibis (Haaland and Magid 1992). Elsewhere 
in the Sahara, for example, the Central and Eastern Sahara, long and not short DWL is present while the presence of short DWL in the Nile Valley is limited to the late 6 millennium BC, which the exception of the odd occurrence in the Kerma and Sai Island regions. Jesse (2004) notes that the overlap appears to be northern Chad. Ehret's (1993: 122-123) linguistic analysis of the Nilo-Saharan family appears to indicate contact between northern Chad and the central Nile Valley.

Like at Jebel Moya, the Late Acacus pottery from the Libyan Sahara was manufactured using the coiling method. The tools used were predominantly evenly serrated combs and occasionally plainedged implements. At Uan Tabu and Uan Telocat, comb rocker stamping was replaced by APS during the pastoral periods; inclusive in the patterns produced by the latter action was smocking (Garcea 1993a: , 1998: , 2001). The pastoral pottery had thinner walls, which makes for ease of transport and mobile food processing.

South of the Acacus region, in Niger at Gobero, 70 burials were excavated at Gobero cemeteries G1 and G3 (Garcea 2013, Sereno et al. 2008). The early and middle Holocene periods were characterized by different burial patterns. The burials from the middle Holocene date to between ca. $5200-2400$ BC. Although Garcea (2013) has designated the latter period as pastoral, only two Bos fragments were uncovered and there are no ovicaprines remains, and there is little evidence for mobility until arguably the end of the middle Holocene occupational phase (Stojanowski and Knudson 2014). One of the Bos fragments was a jaw and it was not found on site but rather on the lakebed out of place, from a site that preserves thousands of specimens with many the most complete ever recoveredsuch as complete turtles and braincases of mammals, a partial skull of a boar, etc. It stands in stark with the fauna from Adrar Bous, which is dominated by hundreds of Bos bones (Clark et al. 2008). On the pottery front, there is "wavy line" décor and a mention of small wave DWL (Garcea 2013: 232), but no quantification or context or provided and neither were any photos. A re-examination of the complete assemblage is underway by Sereno's team (Sereno, pers. comm. 2017), which would be invaluable.

There is, therefore, no data either in the Sahara or the Sudan which suggests décor such as small comb-stamped (dotted) wavy line are connected with pastoralism. However, differential composition of assemblages may hold the key to disentangling the nature of contacts, which can be assessed through the appropriate application of attribute analysis (see, for example, MacDonald 2011 for such an application in the West Sahel).

\section{Discussion}

The issues with typological approaches to pottery studies in the Sahara and Sudan is perfectly encapsulated by statements such as catfish spine being a comb and at the same time claiming that the décor produced using it is incised. For incised wavy lines, cat fish spine has been claimed as the tool based upon it being found amongst the faunal remains (Arkell 1949, Caneva 1987a). It is difficult to differentiate spine and comb décor unless it is rocked and curvature is evident. As further pertinently noted by MacDonald and Manning:

"Cord-wrapped roulettes have been very unevenly described, some authors seemingly choosing not to distinguish single-impressed or pivoted cord-wrapped roulettes from impressed or pivoted comb (see Introduction, this volume; Caneva 1983). In his seminal monograph Early Khartoum, Arkell $(1949,87)$ noted concerning the pottery of the Early Settlement (tenth-ninth millenna BC approximately) that "in general the method was to produce the appearance of basketwork by impressions made in the clay with fairly fine cord or twine." When one consults the very clear photos of some of the sherds concerned, it is readily apparent that we are dealing with cord-wrapped roulettes of some type, with only one potentially rolled example amongst several single impressed and rocked examples 
(Arkell 1949, Plate 76). By the same token, Hays (1974, table 1), in his re-analysis of the 'wavy line' pottery of Khartoum, the Second Cataract and Dongola Reach, characterises the majority as being decorated with either 'woven mat' or 'linear mat'. In this case it is apparent that Hays, like Arkell, confused a good deal of comb-impressed pottery with 'mat impressed' pottery (see for example Arkell 1949, 89 and Plate 81)."

It therefore became clear that in order to address the question of the nature of late Mesolithic interregional connections in the central and south-central Sudan, key pottery assemblages needed to be looked at using a more statistically nuanced and statistically justifiable approach to defining assemblages. Caneva (1985) claimed that Central Saharan peoples brought the so-called dotted wavy line technique and animal management to the Nile Valley. The broadly contemporary radiocarbon dates and an intervening distance of ca. $4000 \mathrm{~km}$ has been used as an argument against this hypothesis (Salvatori 2012, Salvatori et al. 2011, Usai 2004, Usai and Salvatori 2006). However, we do not think this is the real question. It is the forms taken by the décor, the tools used and the motor actions which are the real decider in what could or could not be outside influence or ideas rather than the all-encompassing term DWL which is wholly unsatisfactory. Consequently, although this preliminary study has been forced to used existing descriptions from published collections, it is also a call for a thorough re-think of the approach to pottery analysis in both the Sudan and across the Sahara. The tools used during the manufacturing process must be defined and not merely the patterns that they make: technological aspects have spatial and temporal significance (Gosselain 2000: ,Mayor et al. 2005). These attributes allow for subsequent sorting to identify trends and generate statistically derived typologies, termed attribute clusters. It can also ease inter-regional comparisons. As Gosselain (2000: 193) has stated, "Decoration belongs to a category of manufacturing stages that are both particularly visible and technically malleable, and likely to reflect wider and more superficial categories of social boundaries." Decoration is very susceptible to innovation, and choices are channelled through communities' choices on social identity and codes, and broader aesthetic considerations; within these, components can change (Gosselain 2010).

Sometimes large-scale variation means that this needs to be narrowed down to the frequencies of select attributes from which attribute clusters can be generated. Multi-dimensional datasets permit the study of more than one variable by moving beyond limited characterisations of type membership through separation of data collection, classification and analysis. Each sherd's attributes are recorded, which permit different classifications to be used to examine for patterned variability and to see various phases of practice. The application of such a textured approach enables engagement with complex behaviours to shed light on socio-economic, ideological, political and personal motives reflected by the methods chosen by potters, and permits archaeologists to move beyond mundane and inadequate descriptions such as 'red burnished' or 'dotted wavy line' pottery. Likewise, claiming commonality through the use of a rocker motion, inclusive of its sub-set motion alternately pivoting stamp (Fernández 2003), is equally problematic. In essence, typological classificatory systems ultimately lack sufficient fluidity and subtlety to (a) fully explore situations where overlapping pottery tradition transmissions have occurred, (b) avoid imposing a mask of relative homogeneity upon diverse pottery traditions, and (c) establish chains of transmission in attributes between pottery traditions from neighbouring regions. There is also a danger that typologies, in seeking to have a broad inter-regional utility, may become so stretched or fuzzy as to be unreliable (e.g. any 'wavy line' motif no matter how made or placed becomes a signal of a 'wavy line' type). We do not seek to create a taxonomic hierarchy which would fossilise the diagnostic nested, reoccurring co-variables. Instead, we strongly urge the employment of an attribute system which permits the selection of the appropriate attributes pertinent to the questions being asked (see, for example, Brass (2016), Haour et al. (2010), MacDonald (2011), Mayor et al. (2005), McIntosh (1995)). 
This is why the interest goes beyond the presence or not of an ill-defined "dotted wavy line" category, to the presence of short waves and the tools and motor actions which made them, as well as any other pottery which may be associated with inter-regional contacts with desert peoples and/or the initial introduction of domesticates into central and/or south-central Sudan. Traditionally, it is claimed that the Sudanese Nile Valley has two clusters of pottery traditions: Atbara-Khartoum and the Second Cataract (inclusive of Sai Island). The closest parallels are between the Early Neolithic Nabta Playa - Bir Kiseiba ceramics and the latter's Khartoum Variant. Early Khartoum province sites such as Aby Darbein, El Damer and Aneibis have similar general patterns to the Early Neolithic of Nabta Playa - Bir Kiseiba (Gatto 2002a: 76-77). For the Early Khartoum, for the former in the central Sudan, short wave DWL is only known from Kabbashi and El Qoz (Jesse 2002: 92), apart from Shaqadud Midden. Further south, in south-central Sudan, it is known from Jebel Moya. It is only in Mesolithic assemblages from the late $6^{\text {th }}$ millennium $B C$, and it is also present in select assemblages during the $5^{\text {th }}$ millennium BC Neolithic in Khartoum Province when and where it was produced using two toothed implements.

Salvatori (2012: 451) claims there was a "complete reworking of cultural deposits" at Jebel Moya. However, Brass' attribute analysis of the pottery curated at the British museum (Brass 2016, Brass and Schwenniger 2013) shows there are three clearly distinct assemblages, and field observations from the October 2017 excavation at Jebel Moya argue for distinct occupational phases which can be teased apart. Likewise, the relative sequencing and dates is largely secure for Shaqadud Midden. The presence of short dotted wavy line décor in the late Mesolithic of both sites, while APS occurs in the Neolithic layers at Shaqadud Midden and not in earlier Mesolithic layers; the appearance of APS in the central Sahara is also associated with the Neolithic.

Manning and Timpson (2014, Manning et al. 2015) have modelled the major population collapse across the Sahara at the end of the African Humid Period (ca. $4300-3200$ BC), prior to which there was an earlier decline between ca. $5600-4700$ BC. While attention has focused on Wadi Howar, which effectively links Jebel Marra and the eastern shores of Lake Chad with the Nile, less attention has been paid to another potential route from the central Sahara, Jebel Marra and the Ennedi. Streams from south-eastern Jebel Marra led into the Bahrel-Arab/Bahr-el-Ghazal and terminated at the Soba - White Nile confluence. There is also evidence of connectivity between areas to the north and Central Sudan, which may have become a melting pot of people and ideas at this time. In the southern Gezira at Jebel Moya, potential animal rather than human bones were observed in a gully nearby the trenches which we excavated in 2017; the gully has clearly defined geological strata and the bones are in association with late Mesolithic pottery. During the next field season, we will continue excavating down to bedrock and get a clearer picture of the archaeological and faunal remains in the bottom stratum as well as remove the bones in the gully for full examination by the faunal specialist, Kevin MacDonald.

Until then, it is speculative to say whether limited numbers of cattle were present during the late Mesolithic or not, but the possibility cannot be dismissed. In the Gezira Plain of central and southcentral Sudan, a number of environmental changes occurred during the middle Holocene. The $500 \mathrm{~mm}$ isohyet was north of Jebel Moya near Khartoum, which increased the northern range of the biting Tabanidae fly. The bite of the Tabanidae fly has detrimental effects on the survival rates of cattle (Wickens 1982: 43) and this may help explain why the remains of early cattle have not been found in early-middle Holocene occupational debris in the northern Gezira (Salvatori et al. 2011). Previous large and sometimes temporary swamps were now much reduced in extent (Mubarak et al. 1982). Faunal remains from Jebel et Tomat and Eish Shaheinab are of savanna-inhabiting animals, although swamps were still present along the White Nile near Khartoum. Clay deposition also came to an end in the middle Holocene and the palaeochannels became inactive (Adamson et al. 1982). 
It was at this time that the southern Gezira, where Jebel Moya is situated, became inhabitable and also the time when it may have been possible to cross and establish links between communities residing close to or further away from either side of the White Nile. This desiccation process has been radiocarbon dated in the Al Khiday area, just south of Khartoum, to the $6^{\text {th }}$ millennium BC (Williams and Adamson 1980: 299-300). It is at this time that the Jebel Moya massif was first inhabited during the Holocene.

If confirmed, it would raise questions regarding the timing and nature of its introduction, particularly as such remains are known from Khartoum Province to the north from the $5^{\text {th }}$ millennium BC onwards with large Nile-focused settlements and drier hinterland groups (Chlodnicki et al. 2011: ,Haaland 1987), and it may be that we are dealing with multiple paths of entry of domesticated animals into different regions of the Sudan. At R12 in northern Sudan, Near Eastern cereals were detected in phytoliths in Grave 46 (ca. 5311-5066 BC), near contemporary with cattle and ovicaprid remains from from Middle Neolithic periods A and B (ca. $5000-3500$ BC respectively) (Madella et al. 2014). Phytoliths from contemporary Ghaba in central Sudan show instead a broad-spectrum diet of savanna grasses; there are no contemporary domesticated animals (Madella et al. 2014).

Only future seasons of fieldwork at Jebel Moya, with excavation down to the bedrock directly below Stratum D will potential resolve these and other questions regarding the full composition of the Mesolithic occupation, the composition of the related pottery assemblage(s) and, together with a comprehensive re-analysis of the Shaqadud Midden assemblages at the British Museum and comparative analysis through with new, updated work to be done on the Gobero pottery by Sereno's team who will move away from Caneva's typological classificatory system to more in-depth analysis. 


\section{Acknowledgements}

Brass and Adam, as co-directors of the University College London - University of Khartoum

Expedition to the Southern Gezira mission, wish to thank the Society for Libyan Studies for their generous grant which made possible this research and the 2017 field season at Jebel Moya. The team is further comprised of Dorian Fuller, Kevin MacDonald, Chris Stevens, Iwona KozieradzkaOgunmakin, Rayan Mahjoub Jarelnabi Abdallah, Osman Khalil Alawad and Ammar Awad Mohamed Abdalla. Thanks are also due to Sue Hamilton (Director of the Institute of Archaeology, UCL), Andy Bevan, Patrick Quinn and Scott MacEachern for their expertise and unstinting support, and to the British Museum, Dr Abdelrahman (Director of NCAM) and our NCAM Inspector Fakhri Hassan Abdallah. Finally, Brass wishes to thank Isabelle Vella Gregory for her support and advice. Any errors are the responsibility of the authors. 


\section{References}

Adamson, D., Gillespie, R. and Williams, M. 1982. Palaeogeography of the Gezira and of the lower Blue and White Nile valleys. In Williams, M. and Adamson, D. (eds.) A land between two Niles: Quaternary geology and biology of the Central Sudan, 165-220. Rotterdam: A.A. Balkema.

Addison, F. 1949. Wellcome Excavations in the Sudan: I, Jebel Moya, 1910-1914. Oxford: Oxford University Press.

Arkell, A. 1949. Early Khartoum. Oxford: Oxford University Press.

Arkell, A. 1962. The distribution in Central Africa of one Early Neolithic ware (Dotted Wavy Line pottery) and its possible connection with the beginning of pottery. In Mortelmans, G. and Nenquin, J. (eds.) Actes du Congres Panafricain de Prehistoire et de Vetude du Quaternaire IV, Leopoldville 1959, 283-287. Tervuren.

Arkell, A. J. 1953. Shaheinab: An account of the excavation of a Neolithic occupation site carried out for the Sudan Antiquities Service in 1949-50. Oxford: Oxford University Press.

Bailloud, G. 1969. L'évolution des styles céramiques en Ennedi (République du Tchad). In Lebeuf, J.-P. (ed.) Actes du Premier Colloque linternationale d'archiologie Africaine, Fort-Lamy (République du Tchad) 11-16 Décembre 1966, 31-45. Fort-Lamy: Etudes et documents tchadiens. Mémoire 1.

Barich, B. (ed.) 1987. Archaeology and Environment in the Libyan Sahara: The Excavations in the Tadrart Acacus, 1978-1983. Cambridge Monographs in African Archaeology 23. Oxford: British Archaeological Reports International Series 368.

Barich, B., Belluomini, G., Bonadonna, F., Alessio, M. and Manfra, L. 1984. Ecological and cultural relevance of the recent new radiocarbon dates from Libyan Sahara. In Krzyzaniak, L. and Kobusiewicz, M. (eds.) Origin and early development of food-producing cultures in north-eastern Africa, 411-417. Poznan: Poznan Archaeological Museum.

Brass, M. 2016. Reinterpreting chronology and society at the mortuary complex of Jebel Moya (Sudan). Oxford: Cambridge Monographs in African Archaeology 92, Archaeopress.

Brass, M. and Schwenniger, J.-L. 2013. Jebel Moya (Sudan): New dates from a mortuary complex at the southern Meroitic frontier. Azania 48: 455-472.

Camps-Fabrer, H. 1966. Sur quelques techniques décoratives de la céramique impressionnée saharienne. In scientifique, S. n. d. I. r. (ed.) Congrès Préhistorique de France: Compte rendu de la XVIIle session, 143-154. Paris: Société Préhistorique Francaise.

Camps, G. 1969. Amekni. Neolithique ancien du Hoggar. Paris: Memoire du C.R.A.P.E. 10.

Camps, G. 1974. Les civilisations préhistoriques de l'Afrique du Nord et du Sahara. Paris: Doin.

Camps, G., Delibrias, G. and Thommeret, J. 1973. Chronologie des civilisations prehistoriques du Nord de F Afrique d'apres le radiocarbone. Libyca 21: 65-89. 
Caneva, I. 1983. "Wavy Line" pottery from Saggai 1: An essay of classification. In Caneva, I. (ed.) Pottery using gatherers and hunters at Saggai 1 (Sudan): Preconditions for food production, Origini XII: $155-90$.

Caneva, I. 1985. The prehistory of Central Sudan: Hints for an overview. In Liverani, M., Palmieri, A. and Peroni, R. (eds.) Studi di paletnologia in onore di Salvatore M. Puglisi 425-432. Rome: Universita di Roma 'La Sapienza'.

Caneva, I. 1987a. Pottery decoration in prehistoric Sahara and Upper Nile: a new perspective. In Barich, B. (ed.) Archaeology and Environment in the Libyan Sahara: The Excavations in the Tadrart Acacus, 1978-1983, 231-254. Oxford: BAR International Series, 368.

Caneva, I. 1987b. Recent research in Central Sudan. Nyame Akuma 29: 53-55.

Caneva, I. 1988. El Geili: The history of a Middle Nile environment 7000 BC - AD 1500. Cambridge Monographs in African Archaeology 29. Oxford: BAR International Series 424.

Caneva, I. 1991. Jebel Moya revisited: A settlement of the 5th millennium BC in the middle Nile basin. Antiquity 65: 262-268.

Caneva, I. 1993. Pre-pastoral Middle Nile: Local developments and Saharan contacts. In Krzyzaniak, L., Kobusiewicz, M. and Alexander, J. (eds.) Environmental change and human culture in the Nile Basin and Northern Africa until the second millennium BC, 405-411. Poznan: Poznan Archaeological Museum.

Caneva, I. and Marks, A. 1990. More on the Shaqadud Pottery: Evidence for Saharo-Nilotic Connections during the 6th-4th Millennium B.C. Archeologie du Nil Moyen 4: 11-35.

Caneva, I. and Osman, O. 1990. Late Neolithic pottery in the Gezira, Sudan. Nyame Akuma 34: 27-29. Chlodnicki, M., Kobusiewicz, M. and Kroeper, K. (eds.) 2011. Kadero: The Lech Krzyźaniak excavations in the Sudan. Poznan: Poznan Archaeological Museum.

Clark, J. D. 1989. Shabona: An Early Khartoum settlement on the White Nile. In Krzyzaniak, L. and Kobusiewicz, M. (eds.) Late prehistory of the Nile Basin and the Sahara, 387-410. Poznan: Poznan Archaeological Museum.

Clark, J. D., Goffird-Gonzalez, D. and Associates. 2008. Adrar Bous: Archaeology of a Central Saharan Granitic Ring Complex in Niger. Tervuren: Annals of the Musee Royal de l'Afrique Centrale.

Close, A. E., Schild, R. and Wendorf, F. (eds.) 1984. Cattle-keepers of the eastern Sahara: the neolithic of Bir Kiseiba. Dallas: Department of Anthropology Southern Methodist University: Institute for the Study of Earth and Man Southern Methodist University.

D'Ercole, G. 2017. Ceramic manufacturing techniques and cultural traditions in Nubia from the 8th to the 3rd millennium BC: Examples from Sai Island. Oxford: Cambridge Monographs in African Archaeology 96, Archaeopress.

Di Lernia, S. (ed.) 1999. The Uan Afuda cave: Hunter-gatherer societies of Central Sahara. Arid Zone Archaeology Monographs 1. Firenze: Edizioni All'insegna del giglio. 
Ehret, C. 1993. Nilo-Saharans and the Saharo-Sudanese Neolithic. In Shaw, T., Sinclair, P., Andah, B. and Okpoko, A. (eds.) The Archaeology of Africa: Food, Metals and Towns, 104-125. London: Routledge.

El Mahi, A. and Haaland, R. 1984. Archaeological research in the area of Rabak and Atbara, Sudan. Nyame Akuma 24/25: 28-32.

Fernández, V. 2003. Four thousand years in the Blue Nile: Paths to inequality and ways of resistance. Complutum 14: 409-425.

Gabriel, B. 1977. Zum ökologischen Wandel im Neolithikum der östlichen Zentralsahara. Berlin: Forschungsstation Bardai - Tibesti.

Gabriel, B. 1981. Die ostliche Zentralsahara im Holozan - Klima, Landschaft und Kulturen (mit besonderer Berticksichtigung der neolithischen Keramik). In Roubet, C., Hugot, H.-J. and Souville, G. (eds.) Prehistoire africaine. Melanges offerts au Doyen Lionel Balout, 195-211. Paris: Prehistoire Africaine. Melanges offerts au Doyen Lionel Balout.

Garcea, E. 1993a. Comparing chaines operatoires: Technological, cultural and chronological features of pre-Pastoral and Pastoral ceramic and lithic productions. In Livingstone Smith, A., Bosquet, D. and Martineau, R. (eds.) Pottery manufacturing processes: Reconstitution and interpretation. Acts of the XIVth UISPP Congress, University of Liège, 2001, Symposium 2.1, 215-228. Oxford: BAR International Series 1349.

Garcea, E. 1993b. Cultural Dynamics in the Saharo-Sudanese prehistory. Roma: Gruppo Editoriale Internazionale.

Garcea, E. 1998. From Early Khartoum to the Saharan Neolithic: Ceramics in comparison. CRIPEL 17: 91-104.

Garcea, E. 2001. Uan Tabu in the Settlement History of the Libyan Sahara. Firenze: All'insegna del giglio.

Garcea, E. 2004. An Alternative Way Towards Food Production: The Perspective from the Libyan Sahara. Journal of World Prehistory 18: 107-154.

Garcea, E. (ed.) 2013. Gobero: The no-return frontier. Archaeology and landscape at the SaharoSahelian borderland. Journal of African Archaeology Monograph Series 9. Frankfurt: Africa Magna Verlag.

Garcea, E. A. A. and Hildebrand, E. A. 2009. Shifting social networks along the Nile: Middle Holocene ceramic assemblages from Sai Island, Sudan. Journal of Anthropological Archaeology 28: 304-322.

Gatto, M. 2002a. Ceramic traditions and cultural territories: The Nubian Group in prehistory. Sudan \& Nubia 6: 8-19.

Gatto, M. (ed.) 2002b. Early Neolithic pottery of the Nabta-Kiseiba area: Stylistic attributes and regional relationships. Holocene settlement of the Egyptian Sahara II: The pottery of Nabta Playa. New York: Kluwer Academic/Plenum Publishers. 
Gatto, M. 2006. The Khartoum Variant pottery in context: Rethinking the Early and Middle Holocene cultural sequence. Archeologie du Nil Moyen 10: 57-72.

Gatto, M. 2013. Preliminary report on the most ancient pottery from the Kerma region. In Honeggar, M., Gatto, M., Fallet, C. and Bundi, M. (eds.) Kerma 2012-13, 4-10. Documents de la mission archéologique suisse au Soudan. Hauterive: Université de Neuchâte.

Gehlen, B., Kindermann, K., Linstädter, J. and Riemer, H. 2002. The Holocene occupation of the Eastern Sahara: regional chronologies and supra-regional developments in four areas of the absolute desert. In 8, J. (ed.) Tides of the desert - Gezeiten der Wüste. Contributions to the archaeology and environmental history of Africa in honour of Rudolph Kuper, 85-116. Africa Praehistorica 14. Cologne: Heinrich-Barth-Institut Köln.

Gerharz, R. 1994. Jebel Moya. (Meroitica 14). Berlin: Akademie Verlag. Berlin.

Gosselain, O. 2000. Materializing identities: An African perspective. Journal of Archaeological Method and Theory 7: 187-216.

Gosselain, O. 2010. Exploring the dynamics of African pottery cultures. In Barndon, R., Engevik, A. and $\varnothing$ ye, I. (eds.) The archaeology of regional technologies: Case studies from the Palaeolithic to the Age of the Vikings, 193-226. Lampeter: The Edwin Mellen Press.

Gosselain, O. and Livingstone Smith, A. 2013. A century of ceramic studies in Africa. In Mitchell, P. and Lane, P. (eds.) The Oxford Handbook of African Archaeology, 117-130. Oxford: Oxford University Press.

Gosselain, O. P. 1992. Technology and Style: Potters and Pottery Among Bafia of Cameroon. Man 27: 559-586.

Haaland, R. 1984. Continuity and discontinuity: How to account for a two thousand years gap in the cultural history of the Khartoum Nile Environment. Norwegian Archaeological Review 17: 39-51.

Haaland, R. 1987. Socio-economic differentiation in the Neolithic Sudan. Oxford: B.A.R.

Haaland, R. 1992. Fish, pots and grain: Early and mid-Holocene adaptations in the Central Sudan. African Archaeological Review 10: 43-64.

Haaland, R. and Magid, A. 1992. Radiocarbon dates from Mesolithic sites in the Atbara region, Sudan. Nyame Akuma 37: 17-27.

Haaland, R. and Magid, A. (eds.) 1995. Aqualithic sites along the rivers Nile and Atbara, Sudan. Bergen: Alma Mater.

Haour, A., Manning, K., Arazi, N., Gosselain, O., Guèye, N., Keita, D., Livingstone Smith, A., MacDonald, K., Mayor, A., Mclntosh, S. and Vernet, R. (eds.) 2010. African pottery roulettes past and present: Techniques, identification and distribution. Oxford: Oxbow Books.

Honegger, M. 2004. Settlement and cemeteries of the Mesolithic and Early Neolithic at el-Barga (Kerma region). Sudan \& Nubia 8: 27-32. 
Honegger, M. 2014. Recent advances in our understanding of prehistory in northern Sudan. In Welsby, D. and Anderson, J. (eds.) The Fourth Cataract and Beyond: Proceedings of the 12th International Conference for Nubian Studies, 19-30. London: Peeters.

Huysecom, E., Rasse, M., Lespez, L., Neumann, K., Fahmy, A., Ballouche, A., Ozainne, S., Maggetti, M., Tribolo, C. and Soriano, S. 2009. The emergence of pottery in Africa during the tenth millennium cal BC: new evidence from Ounjougou (Mali). Antiquity 83: 905-917.

Jesse, F. 2002. Wavy line ceramics: Evidence from Northeastern Africa. In Nelson, K. and Associates (eds.) Holocene Settlement of the Egyptian Sahara (Volume 2): The Pottery of Nabta Playa, 79-96. New York: Kluwer Academic/Plenum Publishers.

Jesse, F. 2003. Early ceramics in the Sahara and the Nile Valley. In Krzyzaniak, L., Kroeper, K. and Kobusiewicz, M. (eds.) Cultural markers in the later prehistory of northeastern Africa and recent research, 35-50. Poznan: Poznan Archaeological Museum.

Jesse, F. 2004. No link between the central Sahara and the Nile Valley? (Dotted) Wavy Line ceramics in the Wadi Howar, Sudan. In Kendall, T. (ed.) Nubian Studies 1998. Proceedings of the Ninth Conference of the International Society of Nubian Studies August 21-26, 1998 Boston, Massachusetts, 296-308. Boston: Northeastern University.

Jesse, F. 2010. Early pottery in Northern Africa - An overview. Journal of African Archaeology 8: 219238.

Keech McIntosh, S. 1995. Pottery. In McIntosh, S. (ed.) Excavations at Jenne-jeno, Hambarketolo, and Kaniana (Inland Niger Delta, Mali), the 1981 season, 130-213. Berkeley: University of California Press.

Khabir, A. M. 1987. New Radiocarbon Dates for Sarurab 2 and the Age of the Early Khartoum Tradition. Current Anthropology 28: 377-380.

Kuper, R. and Kröpelin, S. 2006. Climate-controlled Holocene occupation of the Sahara: Motor of Africa's evolution. Science 313: 803-807.

MacDonald, K. 2011. Betwixt Tichitt and the IND: The pottery of the Faïta Facies, Tichitt Tradition. Azania 46: 49 - 69.

Madella, M., García-Granero, J., Out, W., Ryan, P. and Usai, D. 2014. Microbotanical evidence of domestic cereals in Africa 7000 years ago. PNAS 9: e110177.

Manning, K. and Timpson, A. 2014. The demographic response to Holocene climate change in the Sahara. Quaternary Science Reviews 101: 28-35.

Manning, K. and Timpson, A. 2015. Response to "Comment on 'The demographic response to Holocene climate change in the Sahara'". Quaternary Science Reviews 110: 172-175.

Manning, K., Timpson, A., Shennan, S. and Crema, E. 2015. Size reduction in early European domestic cattle relates to intensification of Neolithic herding strategies. PLOS ONE 10: e0141873.

Manzo, A. 1995. Remarks on the Jebel Moya ceramics in the British Museum and their cultural significance. Sudan Archaeological Research Society newsletter 9: 11-19. 
Marks, A. 1991. Shaqadud and the 1982/83 excavations. In Marks, A. and Mohammed-Ali, A. (eds.) The late prehistory of the eastern Sahel: The Mesolithic and Neolithic of Shaqadud, Sudan, 33-64. Dallas: Southern Methodist University Press.

Marks, A. and Mohammed-Ali, A. 1991. The late prehistory of the eastern Sahel: The Mesolithic and Neolithic of Shaqadud, Sudan. Dallas: Southern Methodist University Press.

Mayor, A., Huysecom, E., Gallay, A., Rasse, M. and Ballouche, A. 2005. Population dynamics and Paleoclimate over the past 3000 years in the Dogon Country, Mali. Journal of Anthropological Archaeology 24: 25-61.

McIntosh, S. K. (ed.) 1995. Excavations at Jenne-jeno, Hambarketolo, and Kaniana (Inland Niger Delta, Mali), the 1981 season. Berkeley: University of California Press.

Mohammed-Ali, A. 1991. The Mesolithic and Neolithic ceramics from Shaqadud Midden. In Marks, A. and Mohammed-Ali, A. (eds.) The late prehistory of the eastern Sahel: The Mesolithic and Neolithic of Shaqadud, Sudan, 65-94. Dallas: Southern Methodist University Press.

Mohammed-Ali, A. and Khabir, A. 2003. The Wavy Line and the Dotted Wavy Line Pottery in the Prehistory of the Central Nile and the Sahara-Sahel Belt. African Archaeological Review 20: 25-58.

Mubarak, M., Bari, E., Wickens, G. and Williams, M. 1982. The vegetation of the central Sudan. In Williams, M. and Adamson, D. (eds.) A land between two Niles: Quaternary geology and biology of the Central Sudan, 143-164. Rotterdam: A.A. Balkema.

Nicoll, K. 2004. Records of recent environmental change and prehistoric human activity in Egypt and northern Sudan. Quaternary Science Reviews 23: 561-580.

Otto, K. 1963. Shaqadud: A new Khartoum Neolithic site outside the Nile Valley. Kush XI: 108-115.

Otto, K. 1964. Khartoum-Neolithikum am Jebel Shaqadud. Varia Archaeologica 16: 9-13.

Peters, J. 1991. The faunal remains from Shaqadud. In Marks, A. and Mohammed-Ali, A. (eds.) The late prehistory of the eastern Sahel: The Mesolithic and Neolithic of Shaqadud, Sudan, 197-235. Dallas: Southern Methodist University Press.

Marks, A., Mohammed-Ali, A., Peters, J. and Robertson, R. 1985. The Prehistory of the Central Nile Valley as seen from the Eastern Hinterlands: Excavations at Shaqadud, Sudan. Journal of Field Archaeology 12: 262-272.

Roset, J.-P. 1987. Néolithisation, Néeolithique et post-Néolithique au Niger nord-oriental. Bulletin de I'Association Francaise pour l'Étude du Quaternaire 4: 203-214.

Roset, J.-P. 1996. La ceramique des debuts de l'Holocene au Niger Nord-oriental. Nouvelles datations, bilan des recherches. In Aumassip, G., Clark, J. D. and Mori, F. (eds.) The prehistory of Africa, 175-182. Colloquium XXIX: The most ancient manifestations of Rock- Art in Africa and their "religiousness" Colloquium XXX: The concept of the "Neolithic" in Africa with particular reference to the Saharan region: Forli.

Salvatori, S. 2012. Disclosing archaeological complexity of the Khartoum Mesolithic: New data at the site and regional Level. African Archaeological Review 29: 399-472. 
Salvatori, S., Usai, D. and Zerboni, A. 2011. Mesolithic site formation and palaeoenvironment along the White Nile. African Archaeological Review 28: 177-211.

Schuck, W. 1989. Prahistorische Funde aus Libyen und Tschad. Untersuchungen zur holozanen Besiedlungsgeschichte der ostlichen Zentralsahara. Universitat zu Koln: Unpublished Ph.D dissertation

Sereno, P. C., Garcea, E. A. A., Jousse, H., Stojanowski, C. M., Saliège, J.-F., Maga, A., Ide, O. A., Knudson, K. J., Mercuri, A. M., Stafford, T. W., Jr., Kaye, T. G., Giraudi, C., N'Siala, I. M., Cocca, E., Moots, H. M., Dutheil, D. B. and Stivers, J. P. 2008. Lakeside Cemeteries in the Sahara: 5000 Years of Holocene Population and Environmental Change. PLOS ONE 3: e2995.

Stojanowski, C. and Knudson, K. 2014. Changing patterns of mobility as a response to climatic deterioration and aridification in the Middle Holocene Southern Sahara. American Journal of Physical Anthropology 154: 79-93.

Sutton, J. 1974. The Aquatic Civilization of Middle Africa. Journal of African History 15: 527-546.

Sutton, J. 1977. The African Aqualithic. Antiquity 51: 25-34.

Usai, D. 2004. Early Khartoum and related groups. In Kendall, T. (ed.) Nubian Studies: Proceedings of the Ninth Conference of the International Society of Nubian Studies, 1998, 419-435. Boston: Museum of Fine Arts and Northeastern University.

Usai, D. and Salvatori, S. 2006. Archaeological research south of Omdurman: A preliminary assessment on ceramic and lithic materials from 10-X-6 multistratified mound site along the western bank of the White Nile in Central Sudan. Archéologie du Nil Moyen 10: 203-220.

Vella Gregory, I. 2017. The application of pottery attribute analysis: A case-study from the Neolithic complex of Kordin, Malta. Journal of Archaeological Science: Reports 14: 543-556.

Williams, M. A. J. and Adamson, D. A. 1980. Late Quaternary depositional history of the Blue and White Nile rivers in central Sudan. Rotterdam: A.A. Balkema.

Winchell, F. 2013. The Butana Group ceramics and their place in the Neolithic and Post-Neolithic of Northeast Africa. Oxford: BAR, Cambridge Monographs in African Archaeology 83. 